\title{
Role of the Thymus in Streptococcal Cell Wall-induced Arthritis and Hepatic Granuloma Formation

\author{
Comparative Studies of Pathology and Cell Wall Distribution in Athymic and Euthymic Rats
}

Janice B. Allen, Daniel G. Malone, Sharon M. Wahl, Gary B. Calandra, and Ronald L. Wilder

Arthritis and Rheumatism Branch, National Institute of Arthritis, Diabetes, and Digestive and Kidney Diseases, and Cellular Immunology Section, Laboratory of Microbiology and Immunology, National Institute of Dental Research, National Institutes of Health, Bethesda, Maryland 20205; Merck, Sharp \& Dohme Research Laboratories, West Point, Pennsylvania 19486

\begin{abstract}
Systemic administration of an aqueous suspension of group $A$ streptococcal cell wall fragments to susceptible rats induces acute and chronic polyarthritis, as well as noncaseating hepatic granulomas. To gain insight into the role of the thymus in the pathogenesis of this experimental model, pathologic responses and cell wall tissue distribution were compared in congenitally athymic rats (rnu/rnu) and their euthymic littermates (NIH/ rnu). Within $24 \mathrm{~h}$, both rat strains developed acute arthritis, characterized by polymorphonuclear leukocytic exudate in the synovium and joint spaces. This acute process was maximal at day 3 and gradually subsided. Beginning 2-3 wk after injection, the euthymic, but not the athymic, rats developed the typical exacerbation of arthritis, characterized by synovial cell hyperplasia with villus formation and $T$ helper/inducer lymphocyterich mononuclear cell infiltration. This process eventually resulted in marginal erosions and destruction of periarticular bone and cartilage. Parallel development of acute and chronic hepatic lesions was observed.

Bacterial cell wall antigen distribution and persistence were similar in the athymic and euthymic rats. Cell wall antigens were demonstrated in the cytoplasm of cells within subchondral bone marrow, synovium, liver, and spleen, coincident with the development of the acute lesions, and persisted in these sites, although in decreasing amounts, for the duration of the experiment.

Our findings provide evidence that the acute and chronic phases of the experimental model are mechanistically distinct. The thymus and functional thymus derived-lymphocytes appear not to be required for the development of the acute exudative disease but are essential for the development of chronic proliferative and erosive disease. Induction of disease is dependent upon cell wall dissemination to and persistence in the affected tissues.
\end{abstract}

\section{Introduction}

Erosive polyarthritis can be produced in rats by a single intraperitoneal injection of an aqueous suspension of cell wall fragments from selected bacteria such as group A, B, or C streptococci and some lactobacilli (1-5). A common property of the arthri-

Dr. Wahl is with the National Institute of Dental Research; Dr. Calandra is with the Merck, Sharp \& Dohme Research Laboratories.

Address reprint requests to Dr. Wilder, Bldg. 10, Rm. 9N240, National Institutes of Health, Bethesda, MD 20205.

Received for publication 11 September 1984 and in revised form 29 April 1985.

The Journal of Clinical Investigation, Inc.

Volume 76, September 1985, 1042-1056 togenic cell walls is lysozyme resistance, which allows these cell walls to persist in tissues for prolonged periods of time (6). After cell wall injection acute, symmetric erythema and swelling of the distal joints appear within $24 \mathrm{~h}$, reach maximum severity within 3-5 d, and then subside. This acute reaction develops coincidentally with deposition of cell wall fragments in the synovium $(7,8)$. About 14-21 d after injection, an exacerbation of the arthritis develops and persists for months. This chronic disease is characterized histologically by hyperplasia of the synovial lining cells, infiltration of the synovial sublining area with macrophages and lymphocytes, proliferation of fibroblast-like cells, and erosive destruction of subchondral and periarticular bone and cartilage. It is associated with persistence of cell wall fragments in the synovium.

Although susceptibility to chronic arthritis in this model is dependent upon rat strain and sex $(2,9)$, the role of the thymus and thymus-derived T lymphocytes is controversial. Hunter et al. (10) concluded on the basis of thymectomy studies and skin test responses to cell walls in outbred rats that thymus-dependent immune processes were not involved in the pathogenesis of the arthritis. Because mononuclear cell infiltration is prominent in the chronic synovitis and bacterial cell walls are well-known modulators of mononuclear cell function (7), we have reevaluated the role of the thymus by comparing congenitally athymic rats (rnu/rnu) and their euthymic (NIH/rnu) littermates after injection of group A streptococcal cell walls. Our results provide evidence that the acute and chronic arthritis are mechanistically distinct. The acute arthritis appears to be thymus-independent and is probably the result of a complement-mediated toxic effect of the cell walls, which develops after the deposition of this material in synovium. The later developing chronic arthritis is thymus-dependent and appears to represent a cell-mediated inflammatory reaction, dependent upon the persistence of the cell walls in the mononuclear phagocytic cells in synovium. These conclusions were derived, in part, from the observation that both the congenitally athymic and euthymic rats developed acute polyarthritis, but only the euthymic rats developed the typical chronic, erosive and proliferative polyarthritis. The acute process was characterized by extensive fibrin deposition, edema, and predominantly polymorphonuclear leukocytic infiltration, whereas the chronic disease was characterized by synovial cell hyperplasia, intense $T$ lymphocyte-rich mononuclear cell infiltration that was associated with cartilage destruction and marginal bony erosion. A similar biphasic process was also observed in the livers of the euthymic, but not the congenitally athymic rats.

\section{Methods}

Animals. Female, specific pathogen-free, defined flora, congenitally athymic nude rats (rnu/rnu) and heterozygous, euthymic (NIH/rnu) lit- 
termates, weighing $\sim 100 \mathrm{~g}$ at the initiation of each experiment, were obtained from the Small Animal Section, National Institutes of Health. These outbred strains were derived by crossbreeding with outbred Rowett congenitally athymic nude rats. The congenitally athymic nude homozygotes ( $\mathrm{rnu} / \mathrm{rnu}$ ) lack functional $\mathrm{T}$ lymphocytes as indicated by failure to reject skin allografts, the absence of a delayed hypersensitivity reaction to tuberculin, the inability to generate immunoglobulin $G$ in response to thymus-dependent antigens, and unresponsiveness of spleen cells after stimulation with $\mathrm{T}$ lymphocyte mitogens (11, and Hansen, C. T., personal communication).

The euthymic and athymic littermates were bred and maintained together under specific pathogen-free conditions. Throughout the course of experimental observation, the animals were housed in cages with filter tops (Lab Products, Inc., Maywood, NJ) that were opened only in a laminar flow biological safety cabinet. These animals were tested serologically (Microbiological Associates, Bethesda, MD) at the completion of the experiments for mycoplasma, and the following viruses: reo type 3 , pneumonia virus of mice, encephalomyelitis, Sendai, mouse adenovirus, Toolan H-1, Kilham rat virus, lymphocytic choriomeningitis, and rat coronavirus/sialodacryoadenitis virus. Serologic evidence of infection was never detected in the experimental animals nor was the presence of pathogens found in sentinel animals also maintained in the animal holding areas. As an additional monitor on the health of the animals, gross and histopathologic examination of the lower respiratory tract was done.

Induction and evaluation of arthritis. The preparation of cell wall fragments from group A streptococci and the induction and scoring of the polyarthritis were done as previously described in detail (2). Briefly, a sterile suspension of sonicated streptococcal cell walls in phosphate buffered saline, $\mathrm{pH} 7.4$, was injected intraperitoneally into both athymic and euthymic rats at a dose equivalent to $40 \mu \mathrm{g}$ of cell wall rhamnose per $\mathrm{g}$ of body weight (12). This dose consistently induces severe arthritis in susceptible rats. Extremities distal to the elbow or knee were graded on a scale of $0-4$, based on the number of joints involved, the degree of erythema and swelling, and the degree of distortion of normal joint contours. The scores for each extremity were summed. Thus, the maximum joint score was 16 for each rat. Control rats were injected with an equal volume of phosphate-buffered saline.

Histologic evaluation. Representative animals were examined by histologic techniques at $1,2,3,7,12,21,42,56$, and $84 \mathrm{~d}$ after injection. Tissue specimens were fixed in $10 \%$ buffered formalin, decalcified in $10 \%$ EDTA, if necessary, and stained with hematoxylin and eosin, and phosphotungstic acid-hematoxylin in order to detect fibrin deposition (13). The slides were coded and analyzed for evidence of an inflammatory reaction and/or other tissue abnormalities.

Identification of streptococcal cell wall antigens in tissues by an immunoperoxidase technique. Formalin-fixed tissue was embedded in paraffin, sectioned, and stained for group A streptococcal cell wall antigens using an immunoperoxidase technique $(14,15)$ (ABC VectaStain Kit, Vector Laboratories, Inc., Burlingame, CA). The sections were deparaffinized with two 5-min washes in xylene and rehydrated by sequential rinses in absolute, $90 \%$ and $85 \%$ alcohol. The final rinse was in $0.05 \mathrm{M}$ Tris/0.15 M NaCl buffer, $\mathrm{pH}$ 7.4. All incubations were performed at room temperature in a humid chamber. The rehydrated sections were incubated for $60 \mathrm{~min}$ with rabbit anti-group A streptococci globulin, $0.01 \mu \mathrm{g}$, (Difco Laboratories, Detroit, MI), washed for $5 \mathrm{~min}$ in buffer, and incubated for $30 \mathrm{~min}$ with a biotinylated goat anti-rabbit globulin (ABC VectaStain Kit). The slides were again washed. Endogenous peroxidase activity was exhausted by incubating the sections in $1.5 \% \mathrm{H}_{2} \mathrm{O}_{2}$ in methanol for $10 \mathrm{~min}$. The slides were then washed in two changes of buffer and incubated for $\mathbf{4 5}$ min with VectaStain ABC Reagent (ABC VectaStain Kit) which consists of an avidin and biotinylated horseradish peroxidase complex. The slides were washed and color was developed by immersion in a solution of $0.05 \% \mathrm{wt} / \mathrm{vol} 3,3$, diaminobenzidine tetrahydrochloride (Sigma Chemical Co., St Louis, MO), 0.04\% wt/vol nickel chloride, and $0.003 \%$ hydrogen peroxide in buffer. Sections were counterstained with $2 \%$ methyl green in methanol, dehydrated in three changes of absolute ethanol, cleared in xylene, and mounted in Permount (Fisher Scientific Co., Fair Lawn, NJ) under a glass coverslip. Control stains included sections from saline-injected rats stained as above, as well as sections from cell wall-injected rats stained with normal rabbit globulin. The anti-group A streptococci globulin and the normal rabbit globulin were absorbed with rat liver powder (Sigma Chemical Co.) and were used at the same protein concentration $(0.01 \mu \mathrm{g})$. Specificity was also verified by absorption of the rabbit anti-group A streptococci globulin on group A streptococcal cell walls. This procedure completely eliminated positive staining.

Preparation and characterization of mononuclear cells. Single-cell suspensions of spleen were prepared under aseptic conditions. Spleens were minced, lysed with $0.14 \mathrm{M}$ ammonium chloride, and filtered through sterile gauze. The mononuclear cells were washed thoroughly, and counted and sized on a ZBI Coulter counter integrated with a Channelyzer (Coulter Electronics, Inc., Hialeah, FL).

Lymphocyte proliferation. The ability of the lymphocytes to respond to $\mathrm{T}$ cell mitogens was determined by culturing cells $\left(1 \times 10^{6} / \mathrm{ml}\right)$ in Dulbecco-Vogt's medium (HEM Research, Rockville, MD) containing $100 \mathrm{U} / \mathrm{ml}$ penicillin, $100 \mu \mathrm{g} / \mathrm{ml}$ streptomycin, $2 \mathrm{mM}$ glutamine, 5 $\times 10^{-5} \mathrm{M} 2$-mercaptoethanol, and 5\% heat-inactivated normal rat serum in 96-well flat-bottomed culture plates (Costar, Cambridge, MA). Culture stimuli were phytohemagglutinin (PHA, 'Burroughs Wellcome Co., Greenville, NC) and concanavalin A (Con A, Calbiochem-Behring Corp., San Diego, CA). The cultures were incubated for $3 \mathrm{~d}$ at $37^{\circ} \mathrm{C}$ with $5 \%$ $\mathrm{CO}_{2}$, and pulsed $4 \mathrm{~h}$ before harvest with $0.5 \mu \mathrm{Ci} /$ well of $\left[{ }^{3} \mathrm{H}\right]$ thymidine $\left({ }^{3} \mathrm{H}\right] \mathrm{TdR}$, specific activity $6.7 \mathrm{Ci} / \mathrm{mmol}$, Schwarz/Mann Div., Becton, Dickinson \& Co., Orangeburg, NY). The incorporation of thymidine was determined in a liquid scintillation counter (LKB Instruments, Inc., Gaithersburg, MD).

Interleukin $2(I L-2)$ production and assay. Splenic mononuclear cells $\left(2 \times 10^{6} / \mathrm{ml}\right)$ were cultured in serum-free Dulbecco-Vogt's medium with $5 \mu \mathrm{g} / \mathrm{ml}$ PHA or Con A for $48 \mathrm{~h}$. The cell-free supernatants were assayed for IL-2 activity by their ability to support the growth of the murine IL2 dependent CTL-L line, as previously described (16). The CTL-L cells were cultured in threefold dilutions of a standard supernatant arbitrarily defined as $100 \mathrm{U} / \mathrm{ml}$ and test samples for $48 \mathrm{~h}$ and pulsed with $0.5 \mu \mathrm{Ci}$ $\left[{ }^{3} \mathrm{H}\right] \mathrm{TdR}$. The incorporated radioactivity was determined and the IL-2 activity in test samples was transformed into units utilizing the reciprocal titer of test samples which gave $30 \%$ of maximal incorporated activity of the standard as described (16).

Interleukin 1 (IL-1) production and assay. Spleen cell suspensions $\left(6 \times 10^{6} / \mathrm{ml}\right)$ were incubated for $2 \mathrm{~h}$ at $37^{\circ} \mathrm{C}$ and washed to remove nonadherent cells. The athymic rats routinely had more $\alpha$-naphthyl esterase-positive cells, often representing up to $50 \%$ of the mononuclear cell population. The adherent spleen cells were stimulated for $48 \mathrm{~h}$ with $5 \mu \mathrm{g} / \mathrm{ml}$ streptococcal cell walls or $40 \mu \mathrm{g} / \mathrm{ml}$ lipopolysaccharide (Escherichia coli 055:B5, Difco Laboratories). These supernatants were assayed for IL-1 activity by using thymocytes from 6-8-wk-old $\mathrm{C} 3 \mathrm{H} / \mathrm{HeJ}$ mice as previously described (17). Briefly, single-cell suspensions of thymocytes were prepared and resuspended in RPMI 1640 containing $15 \mathrm{mM}$ Hepes, $5 \%$ fetal calf serum, $100 \mathrm{U} / \mathrm{ml}$ penicillin, $100 \mu \mathrm{g} / \mathrm{ml}$ streptomycin, and $5 \times 10^{-5} \mathrm{M} 2$-mercaptoethanol. Thymocytes were cultured for $72 \mathrm{~h}$ at $1.5 \times 10^{6}$ cells/well in 96-well tissue culture plates in the presence or absence of $1.5 \mu \mathrm{g} / \mathrm{ml}$ PHA and twofold dilutions of the supernatant to be assayed for IL-1 activity. The cultures were pulsed with $0.5 \mu \mathrm{Ci} /$ well $\left[{ }^{3} \mathrm{H}\right] \mathrm{TdR}$ for the final $5 \mathrm{~h}$ of incubation. The incorporated radioactivity was determined and transformed into units by comparison to an IL-1 standard containing $100 \mathrm{U} / \mathrm{ml}$.

Identification of $T$ lymphocytes in synovium by an immunoperoxidase technique. Distal extremities were removed, skinned, trimmed, and then snap-frozen in M-1 embedding matrix (Lipshaw Manufacturing Co., Detroit, MI) by immersion in a mixture of dry ice and acetone. The frozen blocks were stored at $-20^{\circ} \mathrm{C}$ in sealed containers until sectioned for staining. $8-\mu \mathrm{m}$ sections were cut on a cryostat at $-20^{\circ} \mathrm{C}$ (model CT; International Equipment Co., Damon Corp., Needham Heights, MA)

1. Abbreviations used in this paper: Con A, concanavalin A; IL-1, interleukin 1; IL-2, interleukin 2; PHA, phytohemagglutinin; TdR, thymidine. 


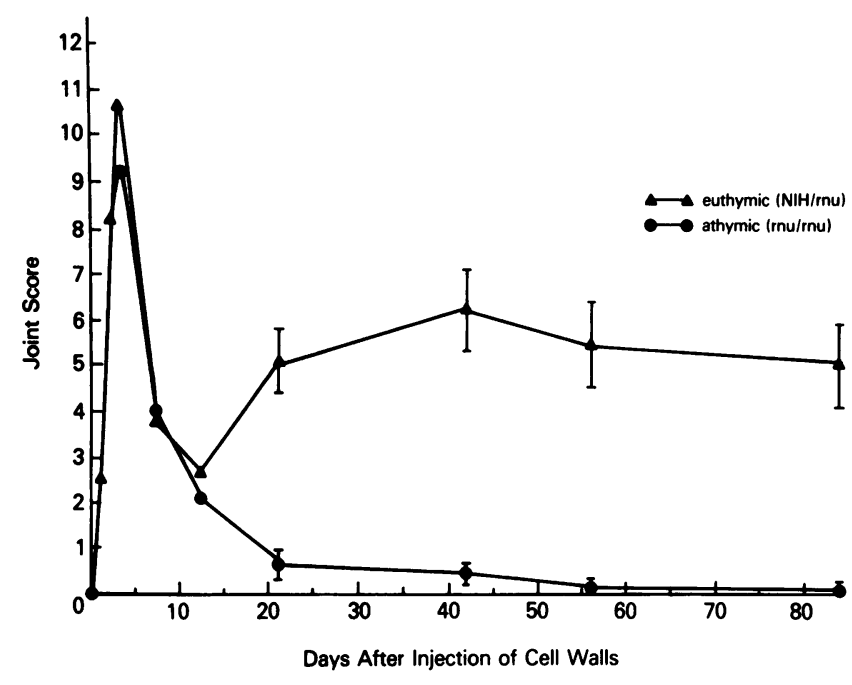

Figure 1. Each point represents the mean joint score \pm standard error of the mean of athymic ( $\bullet$ ) and euthymic $(\Delta)$ rats at intervals after injection of group A streptococcal cell wall fragments.

and placed on glass slides. The slides were dipped into a $60^{\circ} \mathrm{C}$ solution of $0.5 \% \mathrm{wt} / \mathrm{vol}$ gelatin, $0.025 \% \mathrm{wt} / \mathrm{vol}$ chromium potassium phosphate, $0.015 \% \mathrm{wt} / \mathrm{vol}$ thymol in distilled water, and allowed to air dry before tissue was applied.

The sections were fixed in room temperature acetone for $5 \mathrm{~min}$ washed, and then preincubated for $10 \mathrm{~min}$ with a 1:200 dilution of horse serum. Pan $T$ lymphocytes and $T$ lymphocyte subsets were identified by the use of the appropriate mouse monoclonal antibodies, in combination with a sensitive immunoperoxidase-staining technique (ABC VectaStain $\mathrm{Kit})$ as described above for streptococcal cell wall antigens. The monoclonal antibodies used included W3/13 ("pan T lymphocytes"), W3/25 ("helper/inducer T lymphocytes"), and OX8 ("suppressor/cytotoxic T lymphocytes") (Accurate Chemical \& Scientific Corp., Westbury, NY). Control sections were stained with no primary antibody, irrelevant monoclonal antibody, or mouse ascites fluid.

Statistical analysis. Comparisons of data were performed using the Student's $t$ test (18).

\section{Results}

Clinical and histological observations. Female athymic (rnu/rnu) rats and heterozygous euthymic $(\mathrm{NIH} / \mathrm{rnu})$ littermates were given an intraperitoneal injection of streptococcal cell wall fragments at a dose of $40 \mu \mathrm{g}$ of rhamnose/g of body weight and observed for arthritis development. Representative rats were killed at various time points for determination of cell wall distribution and tissue histopathology. Fig. 1 graphically depicts the time course of arthritis, in terms of mean severity, for the athymic and euthymic rats studied. The pertinent observation was the acute monophasic disease in the athymic rats, and the biphasic disease in their euthymic littermates. This difference in disease course between athymic and euthymic animals is further documented in Table I, which summarizes all individual maximum joint scores of the acute (days 0-13) and the chronic (days 14-84) arthritis. Both groups developed acute polyarthritis which reached maximum severity by day 3 and then subsided. The incidence and mean maximum severity of acute disease in the athymic and euthymic rats were not significantly different. In sharp contrast, only the euthymic rats developed the typical exacerbation of arthritis beginning 14-21 d after injection that progressed to severe chronic disease. Two euthymic rats failed to develop the exacerbation of chronic disease, but this was not unexpected because there is wide variability in the incidence and severity of chronic arthritis in outbred animals $(1,2)$, secondary to genetic and hormonal factors. Five athymic rats exhibited minimal joint swelling beyond day 13 , but this extended monophasic disease was clearly different from the biphasic disease in the euthymic rats. Histopathologic analysis supported these conclusions.

As demonstrated histologically in Fig. 2 and summarized in Table II, both the euthymic and athymic rats developed a significant acute inflammatory response. Fig. $2 A$ shows a representative section from a tarsal joint of an athymic female and Fig. $2 C$, the euthymic littermate. This acute reaction, as depicted in the higher magnifications (Fig. $2 B$ and $D$ ), shows that polymorphonuclear leukocytes were the major cell type within the joint space and synovium. Within the synovium, the leukocytes were particularly abundant around blood vessels. Although not clearly evident in these illustrations, but confirmed by phosphotungstic acid-hematoxylin staining, an intense fibrinous exudate was also noted. $12 \mathrm{~d}$ after injection, when the acute reaction was clinically subsiding, the intensity of polymorphonuclear leukocyte infiltration in the synovium was markedly diminished (Table II, Fig. $3 A$ and $B$ ). The predominant infiltrating cells in

Table I. Incidence and Severity of Acute and Chronic Polyarthritis in Athymic and Euthymic Female Rats

\begin{tabular}{|c|c|c|c|c|c|c|c|c|}
\hline \multirow[b]{2}{*}{ Polyarthritis } & \multirow{2}{*}{$\begin{array}{l}\text { No. of rats } \\
\text { injected and } \\
\text { observed }\end{array}$} & \multicolumn{5}{|c|}{ Maximum articular indices (AI) observed" (no. of rats) } & \multirow{2}{*}{$\begin{array}{l}\text { Maximum articular } \\
\text { indices observed } \\
\text { (mean } \pm \text { SEM) }\end{array}$} & \multirow[b]{2}{*}{$P$ values* } \\
\hline & & 0 & $1-4$ & $5-8$ & $9-12$ & $13-16$ & & \\
\hline & $n$ & & & & & & & \\
\hline \multicolumn{9}{|l|}{ Acuteł } \\
\hline $\mathrm{rnu} / \mathrm{rnu}$ & 33 & 0 & 4 & 10 & 15 & 4 & $8.8 \pm 0.59$ & \multirow{2}{*}{ NS } \\
\hline $\mathrm{NIH} / \mathrm{rnu}$ & 27 & 1 & 1 & 5 & 14 & 6 & $9.9 \pm 0.69$ & \\
\hline \multicolumn{9}{|l|}{ Chronic§ } \\
\hline $\mathrm{rnu} / \mathrm{rnu}$ & 21 & 15 & 5 & 1 & 0 & 0 & $0.9 \pm 0.36$ & \multirow{2}{*}{$P<0.001$} \\
\hline $\mathrm{NIH} / \mathrm{rnu}$ & 14 & 2 & 2 & 5 & 5 & 0 & $6.4 \pm 1.0$ & \\
\hline
\end{tabular}

* 100-g female rats were each injected intraperitoneally with an aqueous suspension of streptococcal cell wall fragments at $40 \mu \mathrm{g}$ of rhamnose/g of body weight. ¥ Arthritis observed 0-13 d after injection of streptococcal cell wall fragments. § Arthritis observed 14-84 d after injection of streptococcal cell wall fragments. "Extremities distal to the elbow or knee were graded on a scale of 0-4 based on the number of joints involved, the degree of erythema and swelling, and the degree of distortion of normal joint contours. The score for each extremity was summed; the maximum score per rat was 16. I SEM, standard error of the mean. ** Statistical significance determined by Student's $t$ test; NS, nonsignificant. 

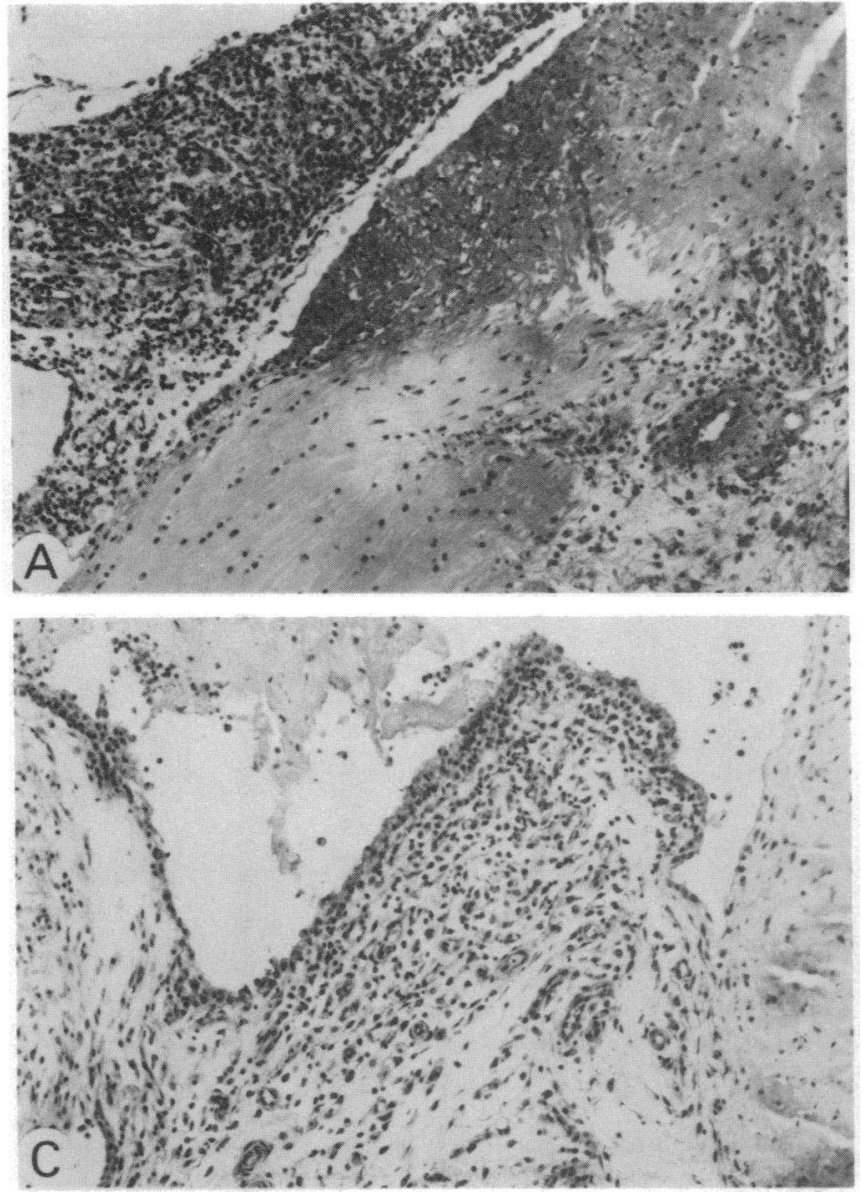

Figure 2. Histologic comparison of athymic and euthymic rats $3 \mathrm{~d}$ after injection of group A streptococcal cell wall fragments. ( $A$ and $B$ ) Tarsal joint from a representative $(n=4)$ athymic female $(\times 99$ and

both the athymic and euthymic joints at this time were mononuclear leukocytes. Low-grade villus hypertrophy and proliferation of synovial sublining fibroblast-like cells were also apparent. In sharp contrast to these early events, major histologic differences between the two groups were noted at later time points (Table II, Fig. 4). For example, Fig. $4 A$ and $B$ show histologic sections of a tarsal joint taken at 12 wk in a representative athymic rat. The inflammatory process was almost completely resolved. No bony erosions or cartilage destruction were observed. The delicate synovial membrane and the general absence of chronic inflammatory cells were particularly noteworthy. On the other hand, sections from the euthymic rats, as shown in Fig. $4 C$ and $D$, were characterized by abnormalities typical of previous studies $(2,6,7)$. These abnormalities included extensive synovial hyperplasia-particularly of the lining cell layer in the form of villi, heavy accumulation of mononuclear cells (macrophages, lymphocytes, and fibroblast-like cells) in the sublining areas, marginal erosions of bone, and cartilage destruction. This destructive process eventually resulted in fibrous replacement of the joint space (not shown).

A histologic comparison of the livers of cell wall-injected athymic and euthymic female rats was also performed (Table II, Figs. 5 and 6). Acutely, the livers of both groups were edematous and had diffuse, low intensity polymorphonuclear infil-
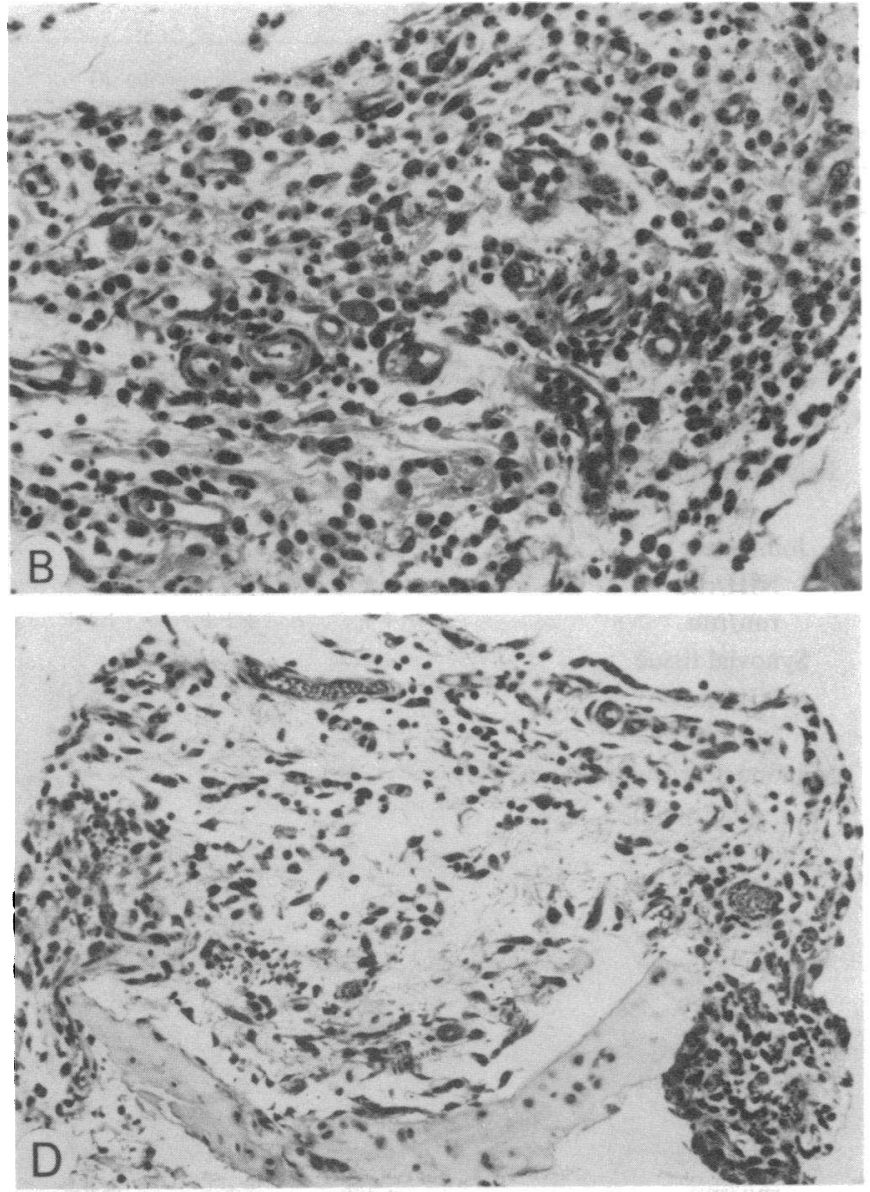

$\times 167$, respectively). ( $C$ and $D$ ) Tarsal joint from a representative ( $n$ $=4)$ euthymic female $(\times 99$ and $\times 167$, respectively).

tration (Fig. $5 A$ and $B$ ). Substantial histologic differences, however, were observed at later time points, as illustrated in Fig. 6. Fig. $6 A$ and $B$ depict a section of liver from a representative athymic rat 12 wk after injection, showing small focal areas of loosely organized mononuclear cells in the periportal regions. In contrast, Fig. $6 C$ and $D$ show a section of liver from a representative euthymic rat. As described in previous studies (2), relatively large noncaseating granulomas were evident, consisting of organized aggregates of mature macrophages and lymphocytes, with a more peripheral rim of fibroblast-like cells. These granulomas were present in the portal areas and in the parenchyma. Plasma cells, multinucleated giant cells, and eosinophils were also present within the granulomas. There was little evidence of hepatic cell death. Thus, in both liver and joints at later time points, the euthymic rats developed much more severe histologic evidence of disease than the congenitally athymic rats.

Cell wall distribution. The distribution and persistence in tissues of the cell wall antigens were compared by immunoperoxidase staining. Consistent with our previous reports, there was a direct correlation between tissue deposition of the cell walls and the development of inflammation at the site of deposition $(7,19)$. Cell wall antigens were deposited in the tissues as early as $1 \mathrm{~d}$ after injection (not shown). By day 3, pronounced staining for cell wall antigens was demonstrated in the synovial tissue, 


\begin{tabular}{|c|c|c|c|c|c|c|c|c|c|}
\hline \multirow[b]{2}{*}{ Tissue abnormalities } & \multicolumn{9}{|c|}{ Time after cell wall injection $(d)$} \\
\hline & 1 & 2 & 3 & 7 & 12 & 21 & 42 & 56 & 84 \\
\hline \multicolumn{10}{|l|}{ Joint } \\
\hline \multicolumn{10}{|c|}{ Synovial lining hyperplasia } \\
\hline $\mathrm{NIH} / \mathrm{mu}$ & - & \pm & + & + & + & ++ & +++ & ++++ & ++++ \\
\hline $\mathrm{rnu} / \mathrm{rnu}$ & - & - & + & + & + & + & - & - & - \\
\hline \multicolumn{10}{|l|}{ Villus formation } \\
\hline NIH/rnu & - & - & + & + & + & ++ & +++ & ++++ & ++++ \\
\hline $\mathrm{rnu} / \mathrm{rnu}$ & - & - & + & + & \pm & - & - & - & - \\
\hline \multicolumn{10}{|c|}{$\begin{array}{l}\text { Polymorphonuclear leukocytic } \\
\text { infiltration }\end{array}$} \\
\hline \multicolumn{10}{|c|}{ Joint space } \\
\hline $\mathrm{NIH} / \mathrm{rnu}$ & ++ & +++ & +++ & + & \pm & + & ++ & +++ & +++ \\
\hline $\mathrm{rnu} / \mathrm{rnu}$ & ++ & +++ & +++ & + & - & - & - & - & - \\
\hline \multicolumn{10}{|c|}{ Synovial tissue } \\
\hline $\mathrm{NIH} / \mathrm{rnu}$ & ++ & +++ & ++++ & + & - & + & + & \pm & \pm \\
\hline $\mathrm{rnu} / \mathrm{rnu}$ & ++ & +++ & ++++ & + & - & - & - & - & - \\
\hline \multicolumn{10}{|c|}{$\begin{array}{c}\text { Mononuclear leukocytic } \\
\text { infiltration }\end{array}$} \\
\hline \multicolumn{10}{|c|}{ Joint space } \\
\hline $\mathrm{NIH} / \mathrm{rnu}$ & \pm & + & + & + & + & + & + & + & + \\
\hline $\mathrm{rnu} / \mathrm{rnu}$ & \pm & + & + & + & + & + & \pm & \pm & \pm \\
\hline \multicolumn{10}{|c|}{ Synovial tissue } \\
\hline $\mathrm{NIH} / \mathrm{rnu}$ & \pm & + & + & ++ & ++ & +++ & ++++ & ++++ & +++ \\
\hline $\mathrm{rnu} / \mathrm{rnu}$ & \pm & + & + & + & + & \pm & - & - & - \\
\hline \multicolumn{10}{|c|}{ Fibrin deposition } \\
\hline \multicolumn{10}{|c|}{ Joint space } \\
\hline $\mathrm{NIH} / \mathrm{rnu}$ & +++ & +++ & +++ & +++ & ++ & ++ & ++ & ++ & ++ \\
\hline $\mathrm{rnu} / \mathrm{rnu}$ & +++ & +++ & +++ & ++ & + & + & - & - & - \\
\hline \multicolumn{10}{|c|}{ Synovial tissue } \\
\hline $\mathrm{NIH} / \mathrm{rnu}$ & +++ & +++ & +++ & +++ & +++ & +++ & +++ & +++ & ++ \\
\hline $\mathrm{rnu} / \mathrm{rnu}$ & +++ & +++ & +++ & ++ & + & + & \pm & - & - \\
\hline \multicolumn{10}{|c|}{ Marginal erosion of bone } \\
\hline $\mathrm{NIH} / \mathrm{rnu}$ & - & - & - & - & + & ++ & ++++ & ++++ & ++++ \\
\hline $\mathrm{rnu} / \mathrm{rnu}$ & - & - & - & - & - & - & - & - & - \\
\hline \multicolumn{10}{|c|}{ Cartilage destruction } \\
\hline NIH/rnu & - & - & - & - & + & + & +++ & +++ & +++ \\
\hline $\mathrm{rnu} / \mathrm{rnu}$ & - & - & - & - & - & - & - & - & - \\
\hline \multicolumn{10}{|l|}{ Liver } \\
\hline \multicolumn{10}{|c|}{$\begin{array}{c}\text { Polymorphonuclear leukocytic } \\
\text { infiltration }\end{array}$} \\
\hline $\mathrm{NIH} / \mathrm{rnu}$ & ++ & +++ & +++ & + & - & \pm & \pm & \pm & - \\
\hline $\mathrm{rnu} / \mathrm{rnu}$ & ++ & +++ & +++ & + & - & - & \pm & \pm & - \\
\hline \multicolumn{10}{|c|}{$\begin{array}{l}\text { Mononuclear leukocytic } \\
\text { infiltration }\end{array}$} \\
\hline $\mathrm{NIH} / \mathrm{rnu}$ & \pm & + & + & \pm & + & ++ & +++ & ++++ & ++++ \\
\hline $\mathrm{rnu} / \mathrm{rnu}$ & \pm & + & + & \pm & \pm & \pm & \pm & \pm & \pm \\
\hline \multicolumn{10}{|c|}{ Hepatic granuloma } \\
\hline $\mathrm{NIH} / \mathrm{rnu}$ & - & - & - & - & - & + & +++ & ++++ & ++++ \\
\hline $\mathrm{rnu} / \mathrm{rnu}$ & - & - & - & - & - & - & \pm & \pm & \pm \\
\hline
\end{tabular}

* Evaluated by two blinded observers. Range: from - , absence of abnormalities, to ++++ , maximum severity.

particularly around blood vessels, in subchondral bone marrow of inflamed joints, and diffusely throughout the livers and spleens from both the euthymic and athymic rats (Fig. 7). Although staining was less intense, cell wall antigens were still demonstrable in the synovial tissues, livers, and spleens from both athymic and euthymic female rats 12 wk after injection (Fig. 8). The 


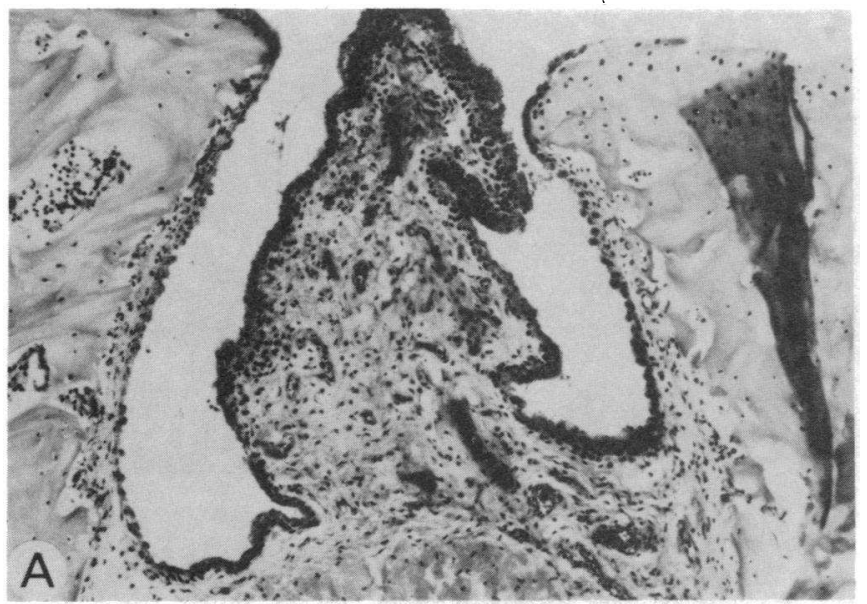

Figure 3. Histologic comparison of athymic and euthymic rats $12 \mathrm{~d}$ after injection of group A streptococcal cell wall fragments $(\times 99)$. $(A)$ Histologic section of a tarsal joint in a representative $(n=5)$ athymic

spleens of both euthymic and athymic rats (Fig. $8 B$ and E, respectively) showed dense staining in the red pulp and none, or very little, in the germinal centers. The cell wall antigens were
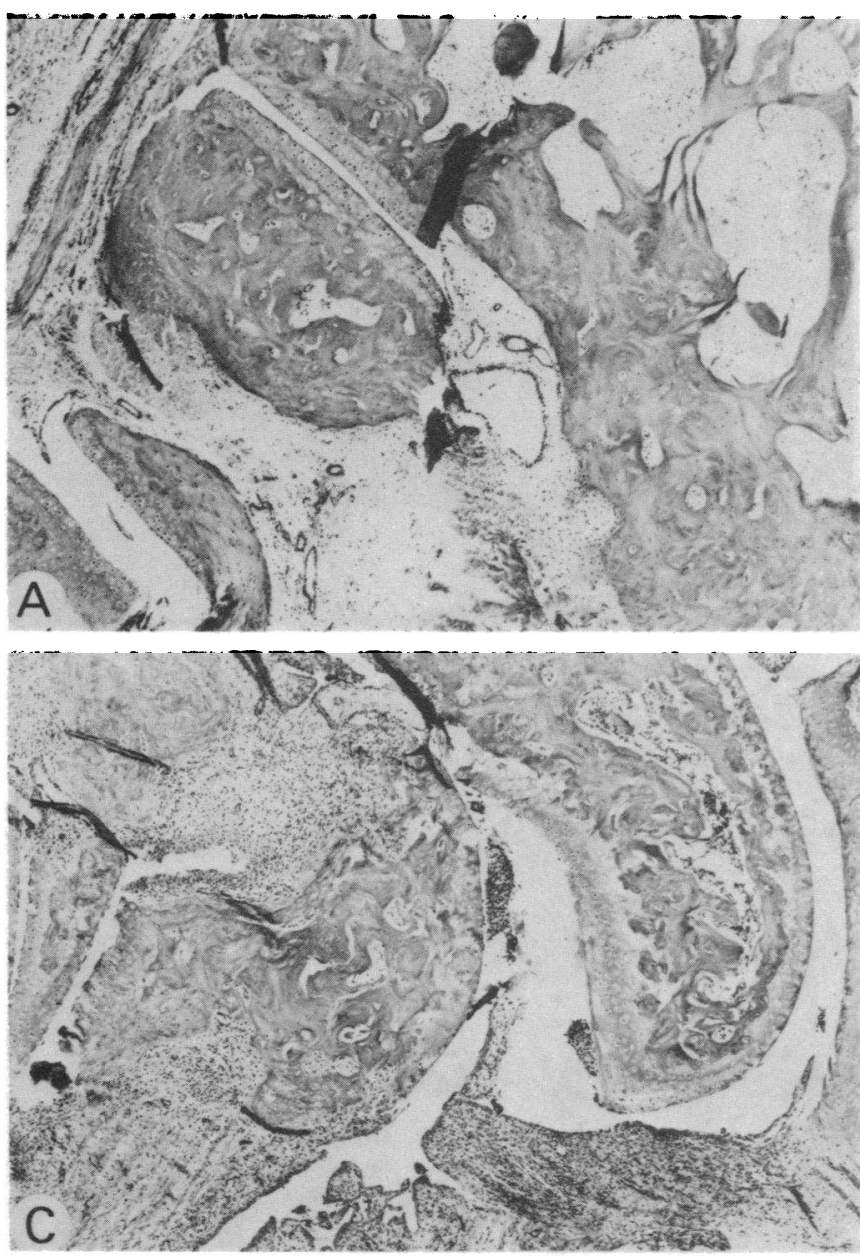

Figure 4. Histologic comparison of athymic and euthymic rats $12 \mathrm{wk}$ after injection of group A streptococcal cell wall fragments. $(A$ and $B)$ Tarsal joint from a representative $(n=12)$ athymic female $(\times 100$ and

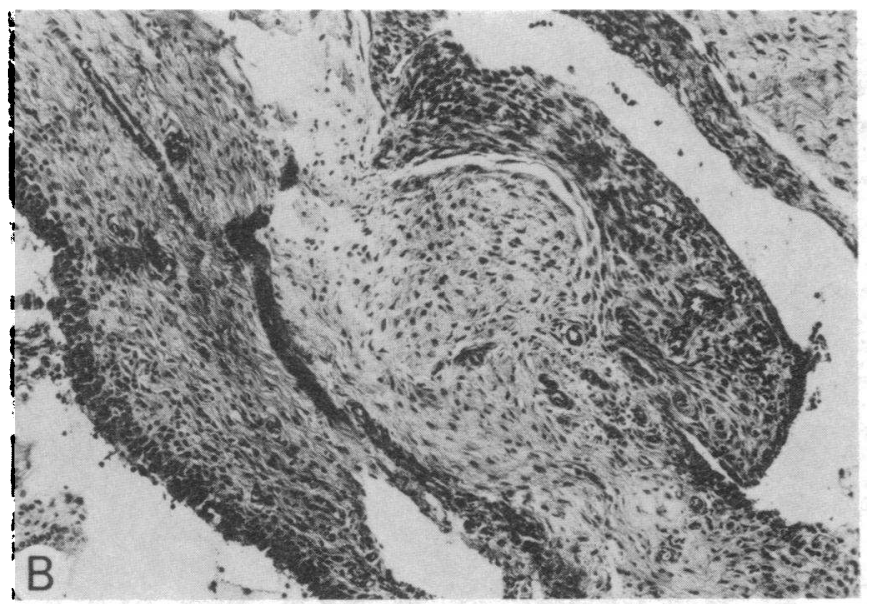

female rat. $(B)$ Histologic section of a tarsal joint in a representative ( $n$ $=5$ ) euthymic female rat.

concentrated mainly in the hepatic granuloma in the euthymic rats (Fig. $8 \mathrm{C}$ ), whereas antigen was more uniformly distributed throughout the liver in the athymic rats (Fig. $8 F$ ). Higher mag-
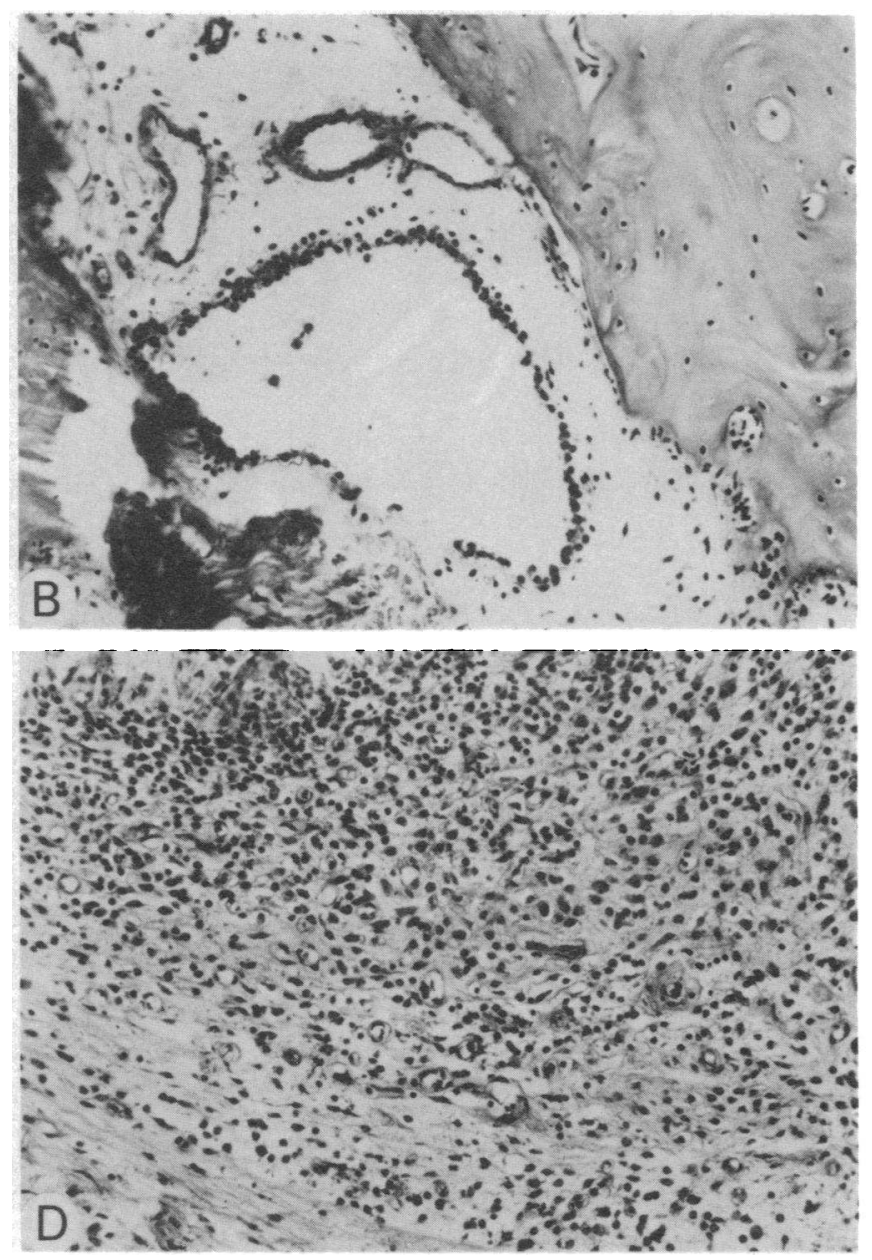

$\times 169$, respectively). ( $C$ and $D)$ Tarsal joint from a representative ( $n$ $=11)$ euthymic female $(\times 100$ and $\times 169$, respectively $)$. 


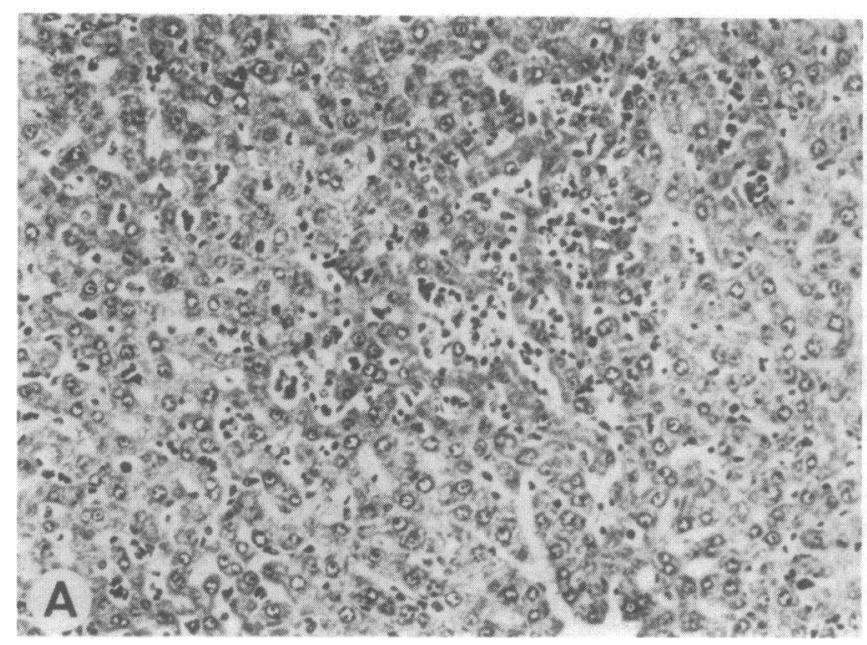

Figure 5. Histologic comparison of liver sections from athymic and euthymic female rats $3 \mathrm{~d}$ after injection of group A streptococcal cell

nification further demonstrates the localization of antigen in the cytoplasm of the phagocytic cells in the synovial tissues, spleens, and livers (Fig. 9). Fig. 10 demonstrates the absence of staining
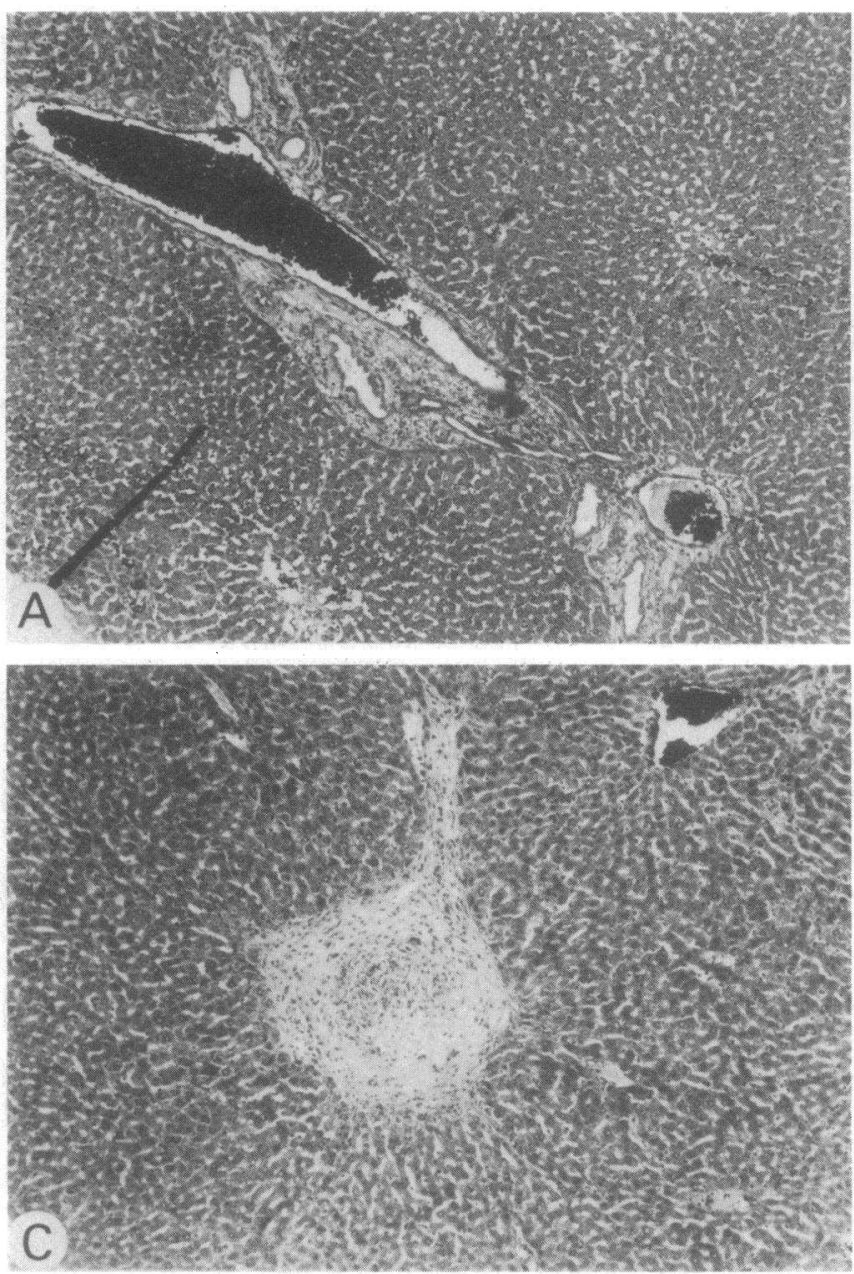

Figure 6. Comparison of liver sections from athymic and euthymic female rats 12 wk after injection of group A streptococcal cell wall fragments. $(A$ and $B)$ Sections from a representative $(n=12)$ athymic rat

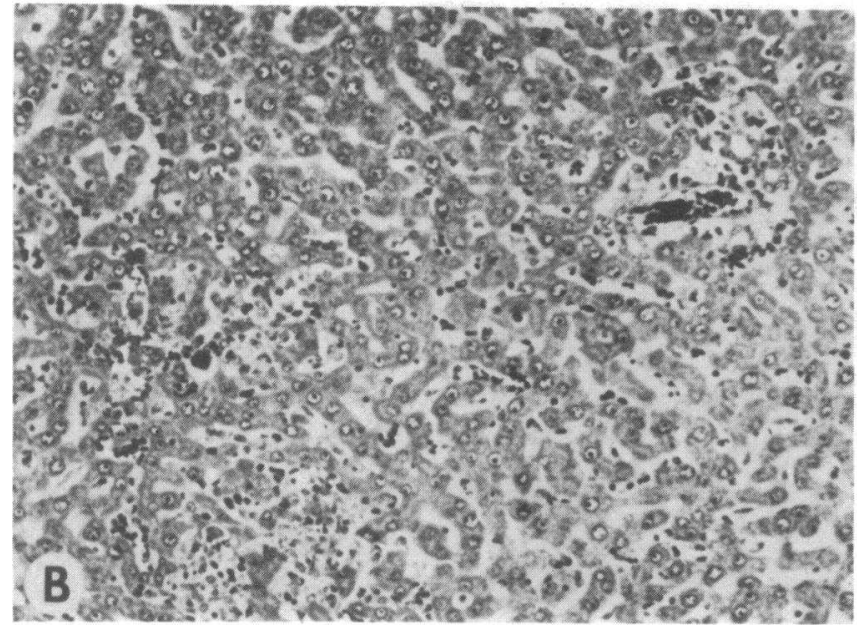

wall fragments $(\times 161) .(A)$ Section from a representative $(n=4)$ athymic rat. $(B)$ Section from a representative $(n=4)$ euthymic rat.

in the controls used for the immunoperoxidase technique. Thus, as summarized in Table III, cell wall antigens were detected in the synovial tissues, bone marrow, spleen, and liver of both eu-
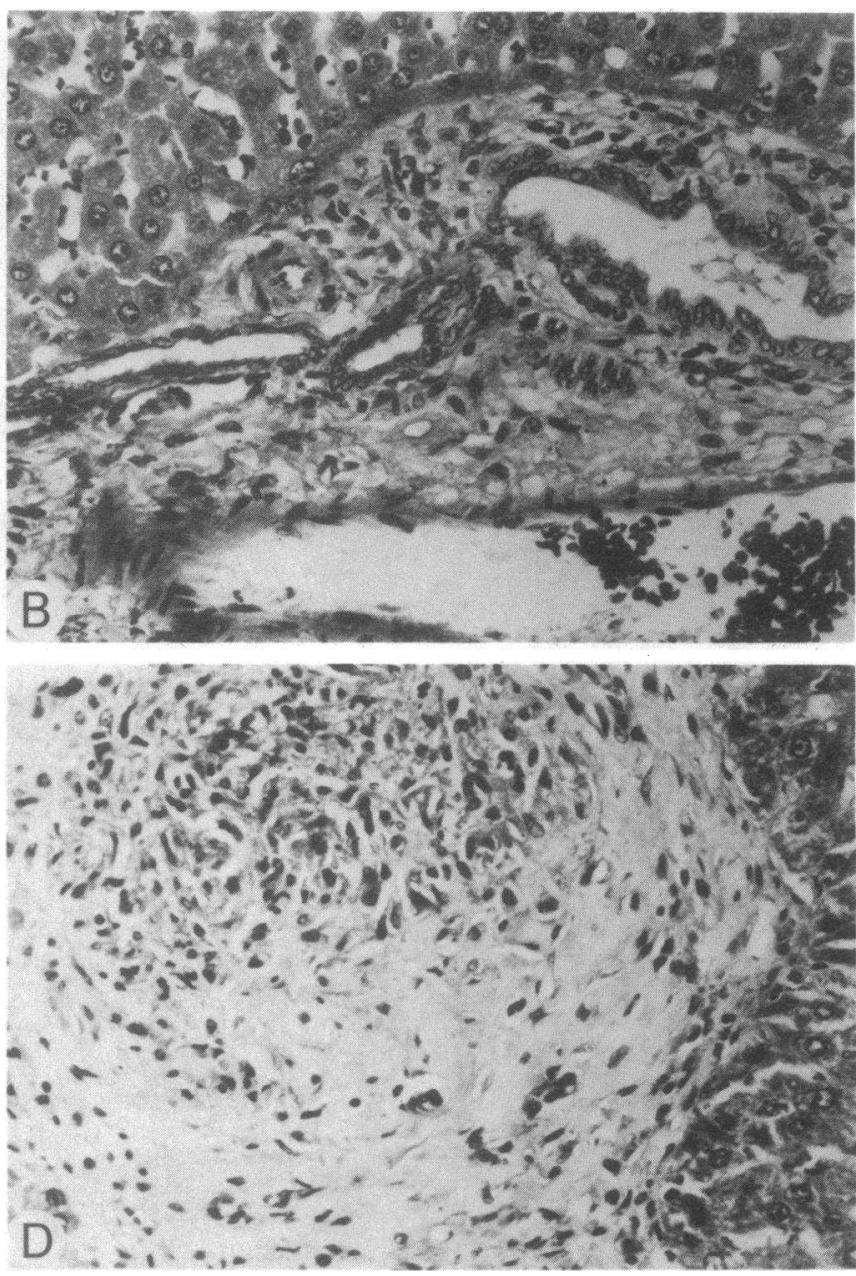

( $\times 62$ and $\times 169$, respectively). ( $C$ and $D$ ) Sections from a representative $(n=11)$ euthymic rat $(\times 62$ and $\times 169$, respectively). 

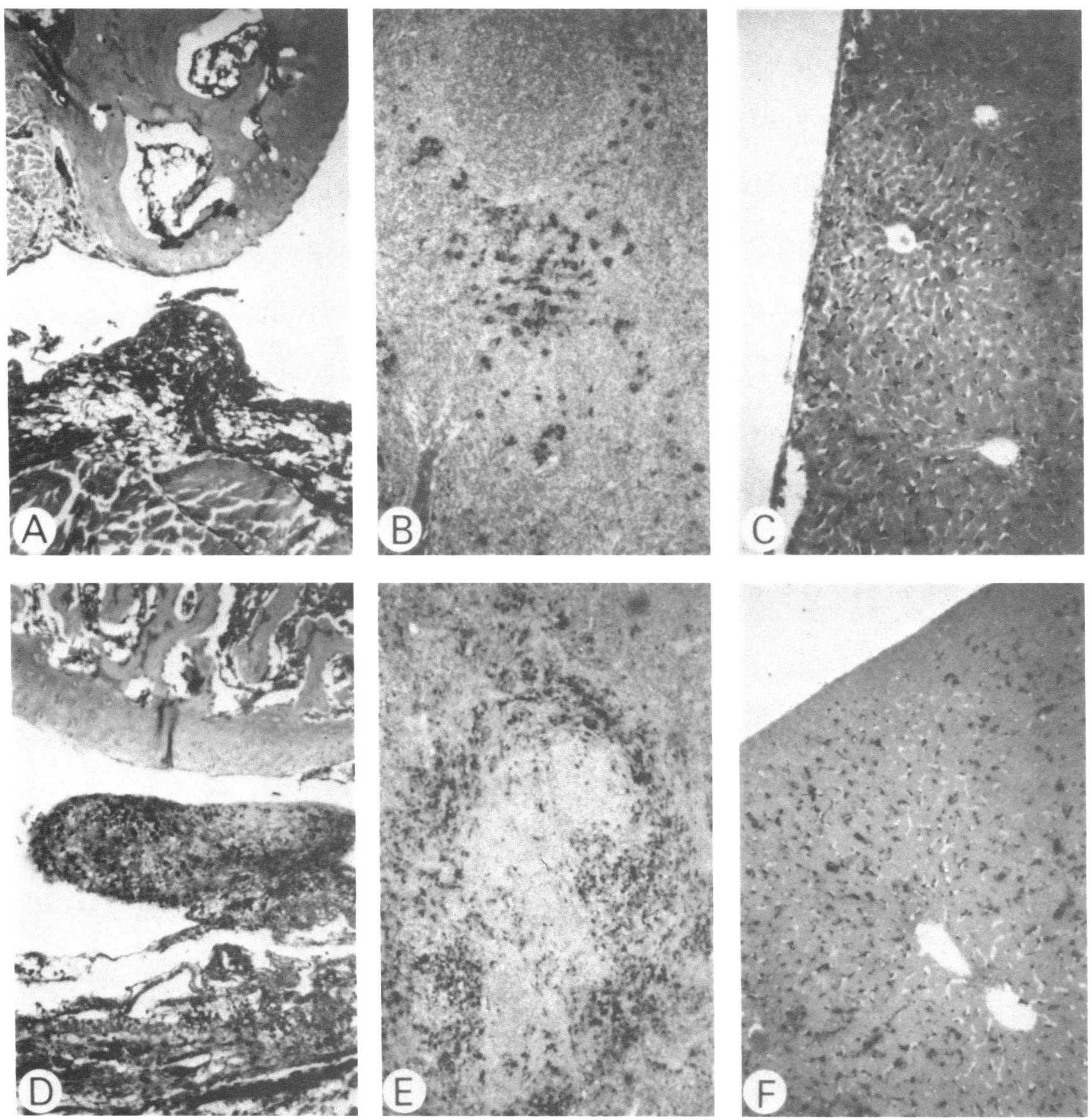

Figure 7. Demonstration of group A streptococcal cell wall antigens in athymic and euthymic female rats $3 \mathrm{~d}$ after injection. The black reaction product precipitate identifies the streptococcal cell wall antigens. The top row of photomicrographs (left to right) shows the specific cytoplasmic immunoperoxidase staining of cells in the synovium, sub-

thymic and athymic rats as early as $1 \mathrm{~d}$ and as late as $12 \mathrm{wk}$ after administration of cell walls. By the techniques employed, distribution to and persistence in various tissues, except as noted above, appeared similar in both rat strains. The important observation was that cell wall antigens were still present in the synovial tissues, bone marrow, liver, and spleen of the athymic rats at $12 \mathrm{wk}$ in the absence of any apparent significant inflammatory reaction. The observations did not support the possibility chondral bone marrow, spleen, and liver, respectively $(\times 49)$, in euthymic female rats. The bottom row shows the immunoperoxidase staining in the synovium, subchondral bone marrow, spleen, and liver, respectively $(\times 49)$, in athymic rats.

that the athymic animals cleared the cell wall antigens more rapidly from their tissues.

Mononuclear cell function. To further confirm the relative absence of functional $\mathrm{T}$ cells in the congenitally athymic rats, we compared splenic mononuclear cells from both the athymic and euthymic female rats in a proliferation assay using $\mathrm{T}$ lymphocyte mitogens as stimuli. Two representative experiments are shown in Table IV. Splenic mononuclear cells from the eu- 

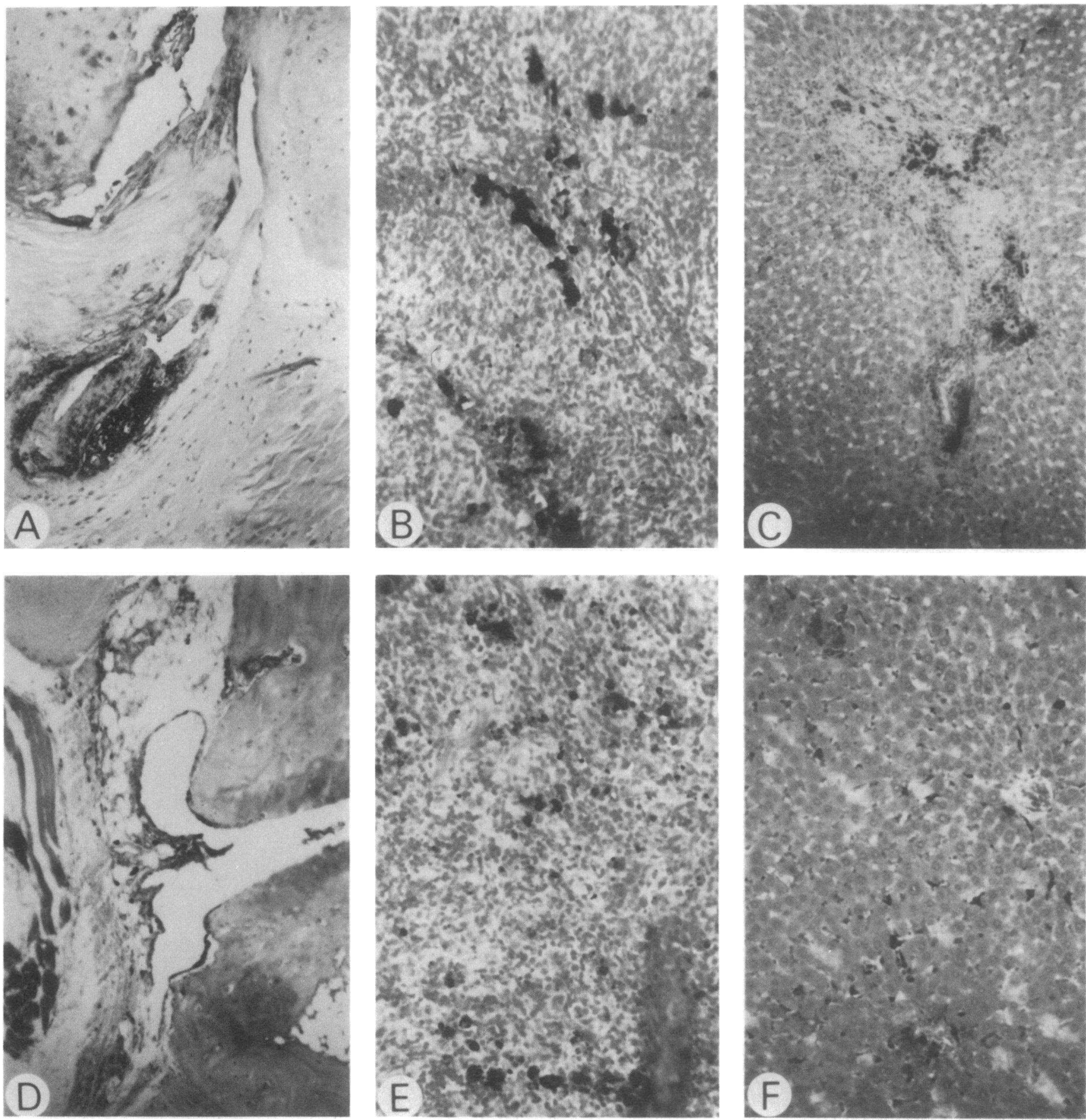

Figure 8. Demonstration of group A streptococcal cell wall antigens in athymic and euthymic female rats 12 weeks after injection. The top row of photomicrographs (left to right) shows the intracytoplasmic im- munoperoxidase staining of cells in the synovium, spleen, and liver, respectively, in euthymic rats $(\times 49)$. The bottom row shows the immunoperoxidase staining of the same tissues in athymic rats $(\times 49)$. thymic (NIH/rnu) rats proliferated well in response to Con $A$ and PHA. In contrast, similar mononuclear cell preparations from the athymic ( $\mathrm{rnu} / \mathrm{rnu}$ ) rats did not proliferate to either Con A or PHA at any concentration tested. To document further the inability of the lymphocytes from the athymic ( $\mathrm{rnu} / \mathrm{rnu})$ rats to participate in cell-mediated immune reactions, their ability to produce the $\mathrm{T}$ cell-derived lymphokine, IL-2, was evaluated. Splenic mononuclear cells were cultured with appropriate $T$ cell stimuli, and their supernatants assayed for the presence of IL-
2. Table $V$ shows a representative experiment that demonstrates that splenic mononuclear cells from euthymic rats, but not athymic rats, produced IL-2 when stimulated with PHA or Con A. In contrast, the adherent monocytes obtained from equivalent numbers of spleen cells from euthymic and athymic rats both produced IL-1 when stimulated with lipopolysaccharide or streptococcal cell walls, indicating that the defect resides in the lymphocyte population. These data further confirm that the athymic rats compared with their euthymic littermates do, in- 

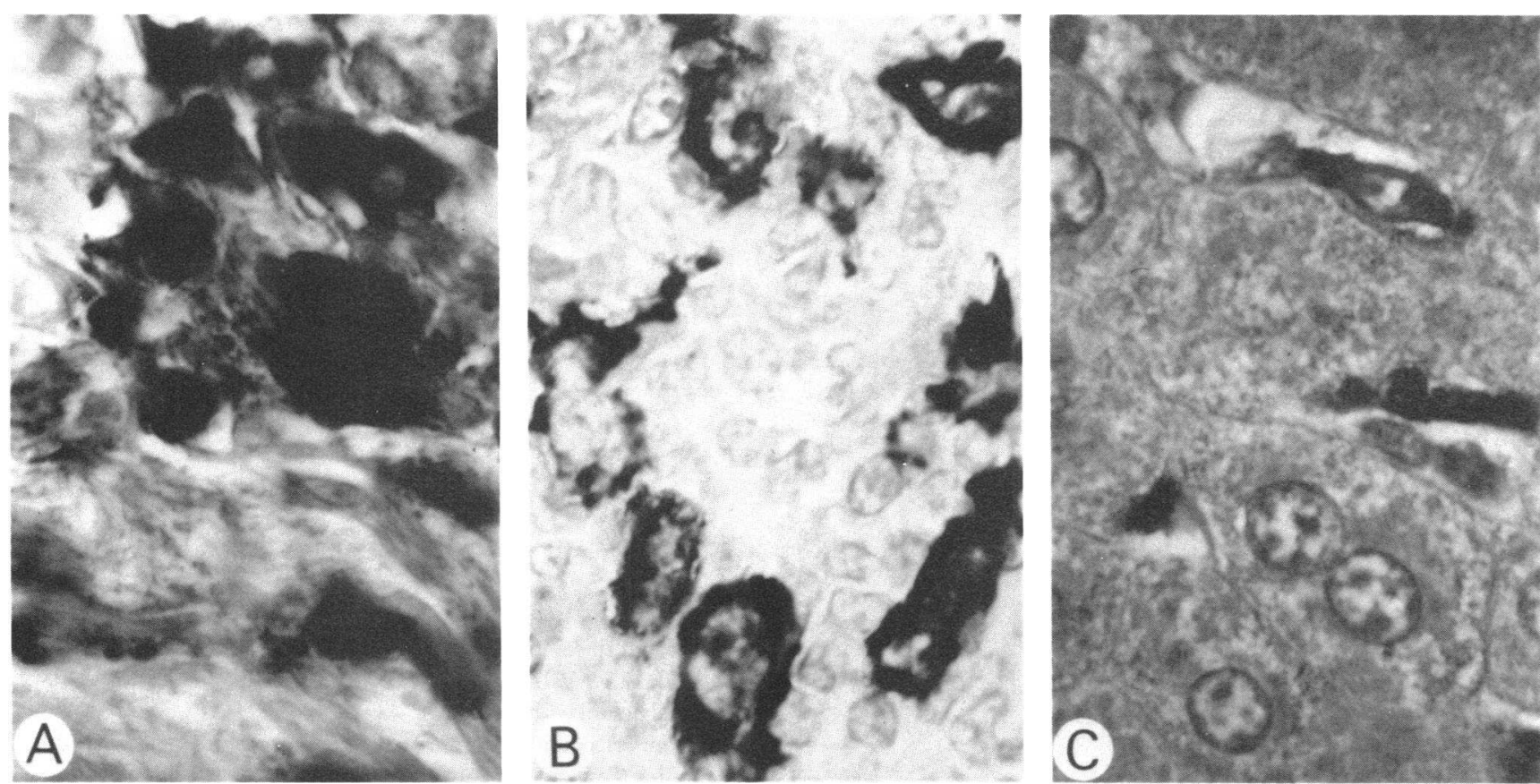

Figure 9. Demonstration of group A streptococcal cell wall antigens in the cytoplasm of phagocytic cells in the synovium $(A)$, spleen $(B)$, and

deed, lack functional $\mathrm{T}$ cells, but that the monocytes when appropriately activated can respond by producing IL-1.

$T$ lymphocytes and $T$ lymphocyte subsets. To provide further evidence that $T$ lymphocytes are required for the generation of the chronic lesions, we stained frozen sections of peripheral joints liver $(C)$ of a representative euthymic rat 12 wk after injection. $(\times 949)$.

from the euthymic and athymic rats. As shown in Fig. $11 \mathrm{~A}$, the synovium from cell wall-injected euthymic rats exhibited highgrade infiltration by lymphocytes that expressed the pan $T$ lymphocyte cell surface marker, W3/13. These lymphocytes tended to form nodules around blood vessels. In the nodules, the ratio
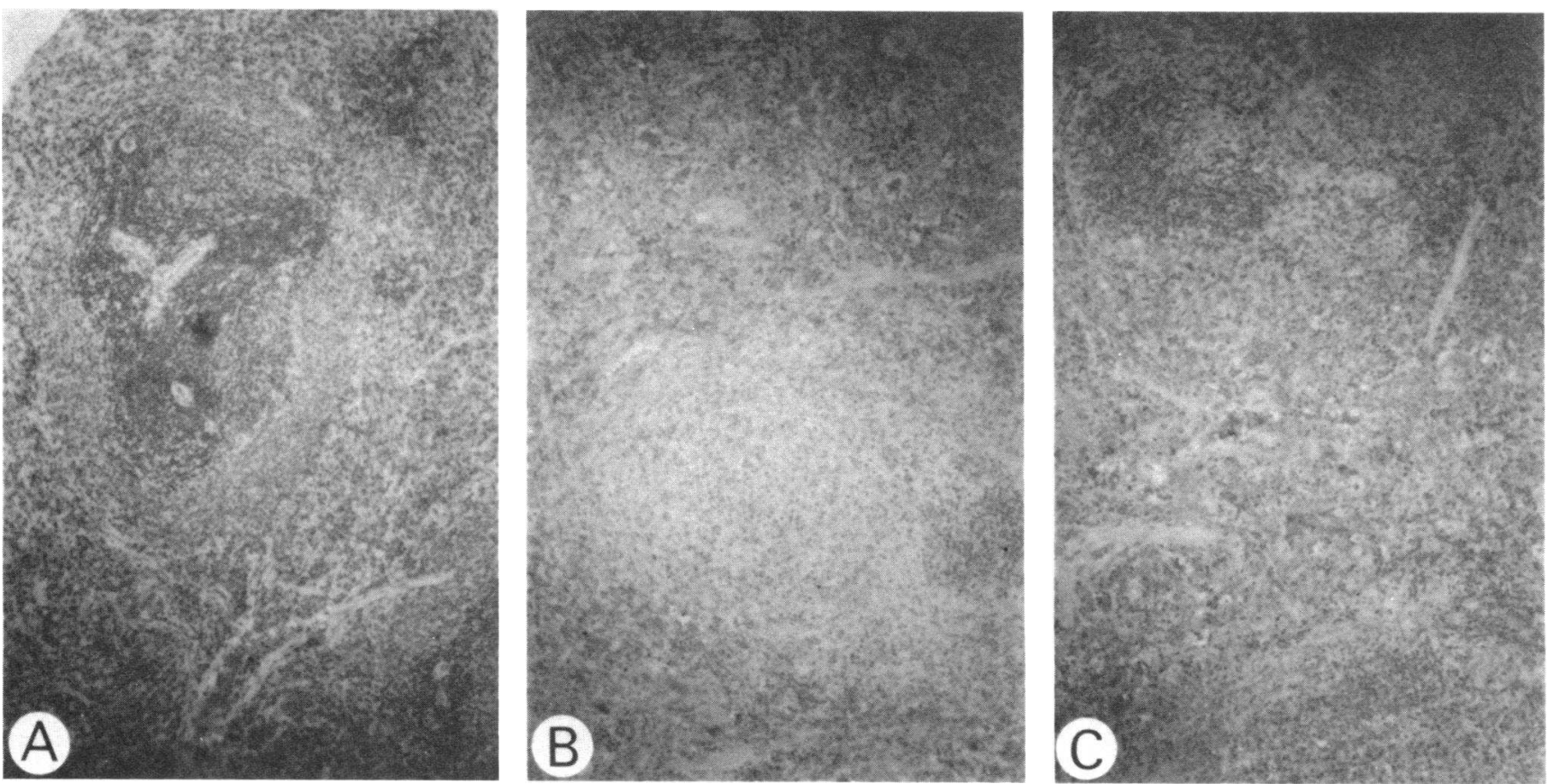

Figure 10. Control immunoperoxidase stains. $(A)$ Section of liver from a saline-injected rat, stained with the rabbit anti-group A streptococci globulin. $(B)$ Section of liver from a cell wall-injected rat, stained with the rabbit anti-group A streptococci globulin which had been absorbed on group A streptococcal cell walls. The absorption has abrogated the staining of the cell wall antigens. $(C)$ Section of liver from a cell wallinjected rat, stained with normal (nonimmune) rabbit globulin. 
Table III. Tissue Distribution and Persistence of Group A Streptococcal Cell Wall Antigens in Cell Wall-injected Euthymic and Athymic Rats

\begin{tabular}{llllll}
\hline \multicolumn{7}{c}{ Time after cell wall injection $(d)^{*}$} \\
\cline { 2 - 6 } Rat & 1 & 3 & 21 & 42 & 84 \\
\hline rnu/rnu & & & & & \\
$\quad$ Bone marrow & +++ & ++++ & ++++ & +++ & +++ \\
Spleen & +++ & ++++ & ++++ & +++ & +++ \\
Liver & +++ & ++++ & ++++ & +++ & +++ \\
Synovium & ++ & +++ & +++ & ++ & + \\
NIH/rnu & & & & & \\
Bone marrow & +++ & ++++ & ++++ & +++ & +++ \\
Spleen & +++ & ++++ & ++++ & +++ & +++ \\
Liver & +++ & ++++ & ++++ & +++ & +++ \\
Synovium & ++ & +++ & +++ & ++ & + \\
& & & & & \\
\hline
\end{tabular}

* Qualitative estimate of relative quantities of cell wall antigens in various tissues based upon the intensity of immunoperoxidase staining as described in Methods. The results represent the mean scores from blinded assessment by three observers.

of W3/25-bearing cells ("T helper/inducer") to OX8-bearing cells ("T suppressor/cytotoxic") was as high as 10:1 (Fig. 11, B and $C$ ). The W3/13- and W3-25-bearing cells tended to form clusters, whereas the OX8-bearing cells were more diffusely scattered. W3/13-bearing lymphocytes were found elsewhere as well, but without a clear predominance of W3/25- or OX8-bearing cells. Variable numbers of cells bearing the W3/13 and W3/ 25 cell surface markers, but generally lacking the OX8 marker, were also observed in the synovium from the congenitally athymic rats, but the intensity of infiltration was strikingly less than observed in the euthymic rats, i.e., density of infiltration in athymic rats, on average, estimated to be $\sim 1 \%$ of euthymic

Table IV. Proliferative Response of Splenic Mononuclear Cells from Euthymic and Athymic Female Rats

\begin{tabular}{|c|c|c|c|c|}
\hline \multirow[b]{3}{*}{ Stimulus* } & \multicolumn{4}{|c|}{$\left[{ }^{3} \mathrm{H}\right] \mathrm{TdR}$ incorporation } \\
\hline & \multicolumn{2}{|l|}{$\mathrm{NIH} / \mathrm{rnu}$} & \multicolumn{2}{|l|}{$\mathrm{mu} / \mathrm{mnu}$} \\
\hline & Exp. 1 & Exp. 2 & Exp. 1 & Exp. 2 \\
\hline & $c p m$ & $c p m$ & $c p m$ & $c p m$ \\
\hline None & 2,482 & 379 & 1,173 & 1,309 \\
\hline \multicolumn{5}{|l|}{ Con A } \\
\hline $1 \mu \mathrm{g} / \mathrm{ml}$ & 9,317 & 21,775 & 350 & 2,162 \\
\hline $5 \mu \mathrm{g} / \mathrm{ml}$ & 94,626 & 83,851 & 1,873 & 2,267 \\
\hline $10 \mu \mathrm{g} / \mathrm{ml}$ & 80,003 & 69,231 & 1,572 & 2,040 \\
\hline \multicolumn{5}{|l|}{ PHA } \\
\hline $1 \mu \mathrm{g} / \mathrm{ml}$ & 25,230 & 8,067 & 310 & 2,091 \\
\hline $5 \mu \mathrm{g} / \mathrm{ml}$ & 50,565 & 40,531 & 706 & 2,727 \\
\hline $10 \mu \mathrm{g} / \mathrm{ml}$ & 14,503 & 4,062 & 393 & 1,936 \\
\hline
\end{tabular}

* Splenic mononuclear cells $\left(2 \times 10^{5} /\right.$ well $)$ were cultured with the indicated concentrations of Con A and PHA for $72 \mathrm{~h}$ and pulsed for $4 \mathrm{~h}$ with $0.5 \mu \mathrm{Ci}$ of $\left[{ }^{3} \mathrm{H}\right] \mathrm{TdR} /$ well. Data are from two representative experiments and represent the mean $\left[{ }^{3} \mathrm{H}\right] \mathrm{TdR}$ of triplicate cultures. The variation in the mean was $\leq 10 \%$.
Table V.IL-1 and IL-2 Production by Euthymic and Athymic Rats

\begin{tabular}{lcc}
\hline Stimulus & $\mathrm{NIH} / \mathrm{mu}$ & $\mathrm{mu} / \mathrm{mu}$ \\
\hline & $\mathrm{IL}-2$ & \\
\cline { 2 - 3 } & $U / \mathrm{ml}$ & $U / \mathrm{ml}$ \\
Control* & $<1$ & $<1$ \\
PHA & 45 & 3 \\
Con A & 142 & $<1$ \\
& & \\
& $\mathrm{IL}-1$ & $U / \mathrm{ml}$ \\
& $U / \mathrm{ml}$ & $<1$ \\
Control‡ & $<1$ & 285 \\
LPS & 87 & 365 \\
SCW & 93 &
\end{tabular}

* $2 \times 10^{6} / \mathrm{ml}$ spleen cells were cultured with no stimulus (control), 5 $\mu \mathrm{g} / \mathrm{ml}$ Con A, or PHA, and the 48-h supernatants were tested for IL-2 activity as described in Methods.

$¥$ Adherent cells derived from $6 \times 10^{6}$ spleen cells were cultured with no stimulus (control), $40 \mu \mathrm{g} / \mathrm{ml}$ lipopolysaccharide (LPS), or $5 \mu \mathrm{g} / \mathrm{ml}$ streptococcal cell walls (SCW) and the 48-h supernatants were tested for IL-1 activity as described in Methods. More adherent cells were routinely obtained from the athymic rats which may explain the relatively higher levels of IL-1 activity in this strain compared to the NIH/ rnu.

rats. Fig. 12 shows the relatively normal appearing synovium 6 wk after cell wall injection with the relative absence of lymphocytes expressing $\mathrm{T}$ lymphocyte-associated cell surface markers.

\section{Discussion}

Although it has previously been reported that thymus-dependent immune processes are not involved in the pathogenesis of group A streptococcal cell wall-induced arthritis in rats (10), other evidence has suggested a possible role for $T$ cells (7). The objective of the present study was to evaluate this controversial conclusion. Our data provide evidence that the thymus is, indeed, required for the development of chronic, erosive arthritis and hepatic granulomas, but plays an insignificant role in the development of the acute, exudative joint and hepatic inflammation.

The mechanisms underlying the biphasic development of streptococcal cell wall-induced arthritis in susceptible rats have received little attention. When considered in the context of previous information, the data presented in our present study support the view that the acute inflammatory lesions, which reach maximum severity $3 \mathrm{~d}$ after injection and subside thereafter, are a direct toxic effect of the cell walls at sites of tissue deposition (7, 19). Group A streptococcal cell walls activate complement components $(20,21)$, and complement components are involved in the early phase of arthritis (20). Moreover, pretreatment of streptococcal cell wall-injected rats with cobra venom to deplete circulatory complement components significantly reduces joint lesions in the acute phase, but does not affect the chronic course (22). Thus, it appears likely that the acute polyarthritis is directly mediated by the local activation of the complement system. Complement activation probably leads to subsequent activation of other humoral effector systems and infiltration of the tissue 

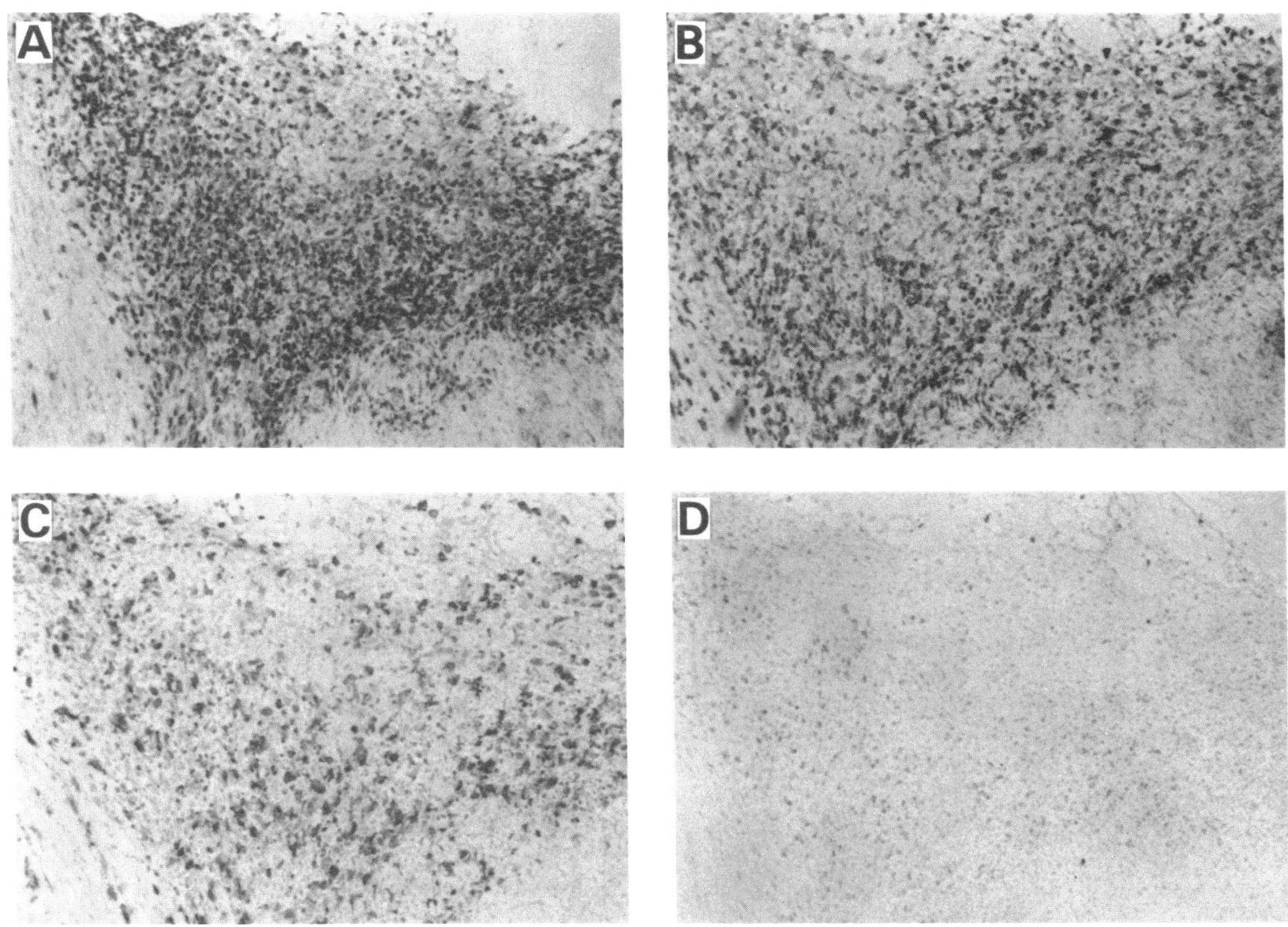

Figure 11. Demonstration of $\mathrm{T}$ lymphocytes in the synovium of a representative euthymic rat $6 \mathrm{wk}$ after injection of group A streptococcal cell walls using the immunoperoxidase technique. $(A-D)$ Serial sections of a synovial nodule stained with the following monoclonal antibodies: $(A) \mathrm{W} 3 / 13$ (pan T lymphocytes); $(B)$ W3/25 (helper/inducer

with acute inflammatory cells. This acute exudative process subsides despite synovial persistence of the bacterial cell wall antigens. A similar process is probably responsible for the acute

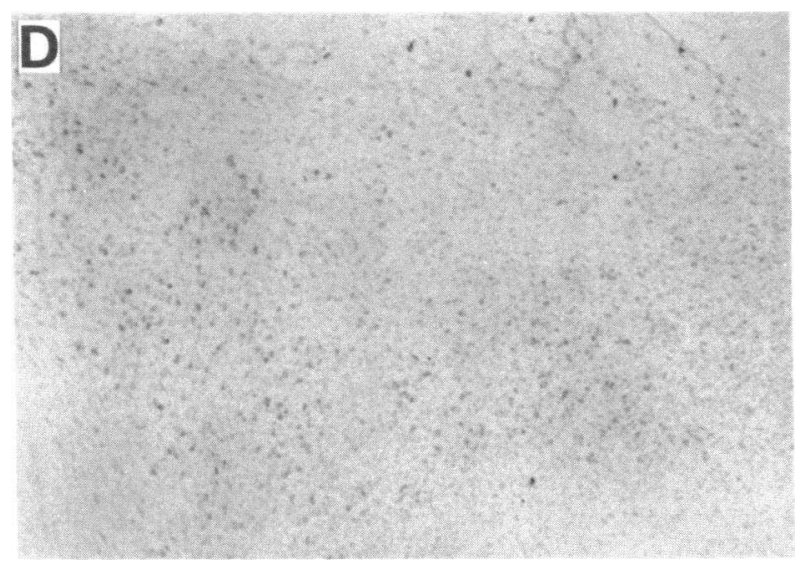

lymphocytes); (C) OX8 (suppressor/cytotoxic lymphocytes); and (D) control (irrelevant monoclonal antibody). Note the intense infiltration of W3/13-, W3/25-bearing lymphocytes and the relative sparse infiltration with OX8-bearing lymphocytes.

disease in the liver. The acute disease was similar in the congenitaly athymic rats and euthymic littermates.

In contrast, our data provide strong evidence that thymus-

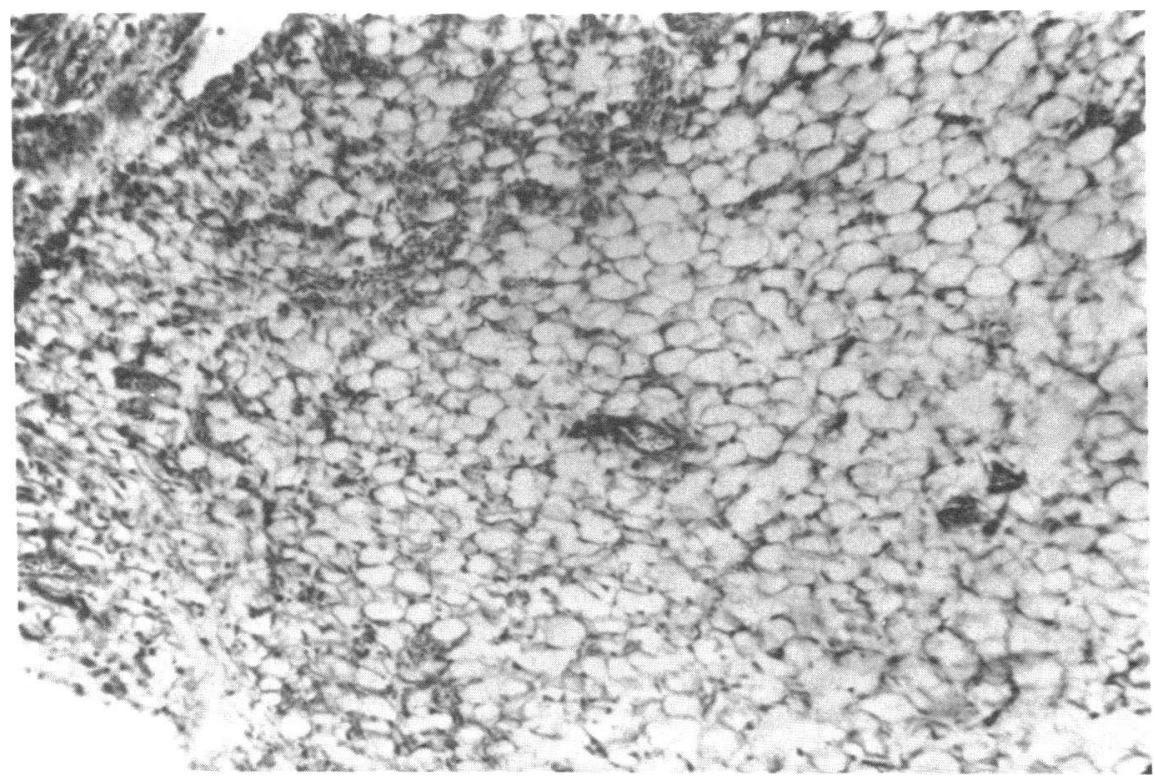

Figure 12. Synovium from an athymic rat 6 wk after injection of group A streptococcal cell walls that was stained with W3/13 (pan T lymphocytes) monoclonal antibody by the immunoperoxidase technique. The tissue appears relatively normal, and positively stained cells were relatively sparse or not demonstrable. Similar results were obtained with the W3/25 and OX8 antibodies (not shown). 
dependent processes play an essential role in the subsequent development of chronic, erosive joint disease. Although both the athymic and euthymic rats developed acute polyarthritis, the athymic rats failed to develop chronic proliferative and erosive polyarthritis. Their euthymic littermates, on the other hand, developed prominent synovial cell hyperplasia, intense infiltration with T-lymphocytes and macrophages, and severe erosion of bone, as well as cartilage destruction, in peripheral joints. The development of arthritis in the athymic and euthymic rats was paralleled by the development of hepatic granulomas. Noncaseating granulomas were only observed in the euthymic rats. Hunter et al. (10) reported the development of both acute and chronic arthritis in neonatally thymectomized outbred rats. In addition, they failed to elicit a delayed-type skin test response in either thymectomized or control rats after intradermal injection of cell wall peptidoglycans during the chronic phases of the disease (10). They concluded that thymus-dependent immune processes are not a pathogenetic factor in the experimental model. Because neonatal thymectomy is technically very difficult, it is possible that these investigators (10) failed to demonstrate the important role of the thymus, because they did not achieve complete neonatal thymectomy. Moreover, it should also be noted that the lack of a delayed-type skin test reaction in response to bacterial cell wall peptidoglycan certainly does not exclude a thymus-dependent process. The same lack of response to peptidoglycan has been observed in adjuvant arthritis, an experimental model clearly dependent upon the thymus (23).

Our present, as well as previous, studies also support the view that the development of chronic arthritis is dependent upon the persistence of the cell walls in phagocytic mononuclear cells in the synovium (7). Chronic arthritis does not develop in the absence of deposition and persistence of cell wall antigens in synovial tissues (7). In the present study, we have demonstrated that the subchondral bone marrow of the distal extremities is also a major site of cell wall deposition and persistence. Because synovial blood vessels originate from periosteal, subchondral, and osteomedullary vessels (24), we suspect that the marrow may provide a depot from which cell walls are mobilized and then deposited in the adjacent synovial tissues. Marrow deposition of the cell walls with subsequent osteoclast activation probably also contributed to the periarticular demineralization that developed in susceptible euthymic rats. Similarly, the deposition and persistence of cell walls in mononuclear phagocytic cells of the liver and spleen were associated with granuloma formation in the euthymic rats. However, despite cell wall dissemination to and persistence in various tissues, significant chronic disease was not observed in the congenitally athymic rats.

The data provide evidence that the chronic phase of disease in susceptible rats represents the development of a T lymphocyteand macrophage-mediated reaction that is a consequence of the persistence of the cell walls in macrophages of the affected tissues. As a possible objection to this conclusion, one might propose that genetically controlled factors other than those regulating thymus-dependent, lymphocyte maturation determined the disparate incidence of chronic arthritis and hepatic granuloma development that we observed between the heterozygous euthymic $(\mathrm{NIH} / \mathrm{rnu})$ and homozygous athymic (rnu/rnu) rats. Infection in the athymic rats, background susceptibility, and resistance genes distinct from the rnu gene(s), and phenotypic effects of the rnu gene(s) unrelated to the thymic development (pleiotropy) are potentially relevant issues.

Infection in the athymic rats clearly appears unlikely. No evidence for pathogenic infection was found during these experiments in either the euthymic or athymic rats, presumably because of the rigorous efforts that we made to maintain a pathogen-free environment. No unexpected mortality or growth retardation were observed. With regard to background susceptibility genes unrelated to the rnu gene(s), it should be noted, as shown by previous studies $(2,9)$, that such gene loci undoubtedly exist, but, for several reasons, they are highly unlikely to have determined the disparate incidence of disease in the euthymic and athymic rats. First, the rats used in this study were from a specific pathogen-free common source (Small Animal Section, National Institutes of Health). Secondly, we studied only female littermates, and thirdly, all the rats were progeny of heterozygous (NIH/rnu) females and homozygous (rnu/rnu) males. This breeding strategy and experimental design resulted in production of about equal numbers of homozygous and heterozygous females. Thus, susceptibility and resistance background genes that were not linked to the rnu gene(s) were, in theory randomly distributed in the progeny. Consequently, these genes were highly unlikely to have determined the differences observed between euthymic and athymic rats. Background susceptibility and resistance genes linked to the rnu gene(s) also seem unlikely to have been important because the mutant rnu gene(s) was present in both experimental groups, i.e., $\mathrm{NIH} / \mathrm{rnu}$ heterozygotes and $\mathrm{rnu} / \mathrm{rnu}$ homozygotes. Because homozygosity at the rnu gene(s) and the athymic, T-lymphocytic function-deficient phenotype are tightly associated (i.e., recombinants have never been observed), we must conclude, on the basis of current data, that the rnu gene(s) itself and not a linked or unlinked gene, determined the experimental differences observed.

The issue of pleiotropic effects of the rnu gene(s) is, at present, unresolvable. It is clear that homozygosity of the mutant rnu gene(s) results in phenotypic effects other than the absence of a thymus and a failure to develop mature, functional T-lymphocytes, e.g., absence of hair (nude). This situation could arise, for example, if a single enzyme required for both hair and thymic development, were absent or defective. We concede that it is possible that phenotypic abnormalities (dependent upon homozygosity of the rnu gene[s]) not obviously related to the lack of a thymus and functional $\mathrm{T}$ lymphocytes may have been important, but additional information makes this less likely. We also demonstrated by immunoperoxidase-staining techniques that $\mathrm{T}$ lymphocytes, particularly of the $\mathrm{T}$ helper/inducer subset, were a major component of the synovial infiltrates, in the chronic phase of the disease in the euthymic rats. Although cells bearing similar cell surface markers were present in the synovial tissues of cell wall-injected congenitally athymic rats, the intensity of infiltration was strikingly less than that in the euthymic rats. This finding is consistent with previous reports that the athymic nude rat has a small proportion of lymphocytes that bear markers considered specific for $\mathrm{T}$ lymphocytes, although they are grossly impaired in expressing $T$ cell functions (25).

Additional information supporting a role for $\mathrm{T}$ lymphocytes is our observation that the immunoregulatory drug, cyclosporin A, a drug that profoundly inhibits T-inducer lymphocyte activation without apparent effects on $T$ suppressor cells, markedly suppressed the development of chronic arthritis and hepatic 
granuloma formation. The drug, as is consistent with observations in athymic rats, has no significant effect on the development of the acute exudative inflammation (26, and Yocum, D. E., J. B. Allen, S. M., Wahl, and R. L. Wilder, manuscript submitted for publication). In addition, we previously demonstrated that mononuclear cells from cell wall-injected rats spontaneously produce in vitro several factors thought to be important in chronic inflammation, such as lymphocyte-derived chemotactic factor (7). Taken together, these data provide strong evidence that $\mathrm{T}$ lymphocyte-mediated immunologic processes play a major role in the pathogenesis of the chronic phases of this experimental model. It is hoped that future experiments (thymus transplants, cell transfer studies, etc.) will further clarify this issue.

The detailed mechanisms responsible for the production of tissue injury are not yet clear, but, as suggested above, it appears that the persistent cellular reaction is associated with the production of various monokines, lymphokines, and degradative enzymes. For example, we have demonstrated that collagenase and prostaglandin $\mathrm{E}_{2}$ are spontaneously secreted by the diseased synovial tissues when cultured in vitro (27). The action of these substances and other neutral proteases, as well as that of various lysosomal hydrolases, probably results in degradation of connective tissue proteins. In addition, various cytokines are probably produced that activate osteoclasts, fibroblasts, and other synovial cells in adjacent tissues of the joint. The activation and probably the proliferation of these cells may result in additional tissue degradation and may provide the final common pathway for joint destruction. Similar processes probably occur at other sites of cell wall deposition such as liver and spleen.

Of additional interest relevant to the issue of mechanisms of tissue injury were our observations that adherent mononuclear cells derived from spleens of the congenitally athymic rats produced as much or more of the monokine, IL-1, after in vitro stimulation with streptococcal cell walls and other stimuli, as did the euthymic rats but, as noted, the athymic rats lacked functional T cell activity. IL-1 has been suggested by some investigators to be a critical mediator in various chronic synovitides in humans because of its reported ability to induce synovial cell proliferation and activation (28). Our data suggest the possibility that IL-1 in the absence of significant numbers of functional T cells or their products is not a sufficient stimulus for the development of chronic erosive synovitis, at least in the cell wallinduced arthritis model. In any event, our findings provide new insights into the pathogenesis of the streptococcal cell wall-induced model of chronic inflammation. They may provide insight into the pathogenesis of chronic inflammatory diseases such as rheumatoid arthritis in that evidence has been provided that similar T lymphocyte- and macrophage-mediated immunologic processes appear to be important in this disorder $(29,30)$.

Our findings also parallel those of many investigators who have explored the role of the thymus in the pathogenesis of other models of arthritis (31-41). Klareskog et al. (31) investigated the role of the thymus in collagen II-induced arthritis in athymic and euthymic rats and concluded that functional $\mathrm{T}$ cells are needed for the development of destructive arthritis. Adjuvant arthritis also appears to be mediated by the $T$ lymphocyte, because it can be passively transferred to normal rats by immune lymphocytes but not by antisera $(32,33)$. Also, the fact that heterologous antilymphocyte serum or globulin completely suppresses the induction of adjuvant arthritis (34) is fur- ther evidence implicating the $\mathrm{T}$ lymphocyte. Koshashi et al. found that muramyl-dipeptide in oil, a synthetic adjuvant, induces severe polyarthritis in euthymic rats, whereas congenitally athymic nude rats do not develop the disease $(40,41)$. Our findings reported here provide a new approach to explore the role of the thymus and the cellular processes involved in the pathogenesis of acute and chronic inflammatory disease.

\section{Acknowledgments}

We would like to thank Ms. Toni Vaughn for her assistance in preparing the manuscript and Ms. Sue Dougherty in assays of the interleukins. We also gratefully acknowledge Dr. Rose Mage and Dr. Carl Hansen for their suggestions.

\section{References}

1. Cromartie, W. J., J. C. Craddock, J. H. Schwab, S. K. Andele, and C. H. Yang. 1977. Arthritis in rats after systemic injection of streptococcal cells or cell walls. J. Exp. Med. 146:1585-1602.

2. Wilder, R. L., G. B. Calandra, A. J. Garvin, K. D. Wright, and C. T. Hansen. 1982. Strain and sex variation in the susceptibility to streptococcal cell wall-induced polyarthritis in the rat. Arthritis Rheum. 25:1064-1072.

3. Clark, R. L., J. T. Cuttino, S. K. Anderle, W. J. Cromartie, and J. H. Schwab. 1979. Radiologic analysis of arthritis in rats after systemic injection of streptococcal cell walls. Arthritis Rheum. 22:25-35.

4. Calandra, G. B., R. Wilder, J. Garvin, C. Hansen, and K. Wright. 1982. Genetic analysis of the development of group A streptococcal cell wall mediated arthritis in rats. In Basic Concepts of Streptococci and Streptococcal Diseases. S. E. Holm and P. Christensen, editors. Reedbooks, Ltd., Surrey, England. 313-314.

5. Lehman, T. J. A., J. B. Allen, P. H. Plotz, and R. L. Wilder. 1983. Polyarthritis in rats following the systemic injection of Lactobacillus casei cell walls in aqueous suspension. Arthritis Rheum. 26:1259-1265.

6. Wilder, R. L. Etiologic considerations in rheumatoid arthritis. 1984. In Evolving Concepts of Pathogenesis and Therapy of Rheumatoid Arthritis. J. L. Decker, moderator. Ann. Intern. Med. 101:820-824.

7. Wilder, R. L., J. B. Allen, L. M. Wahl, G. B. Calandra, and S. M. Wahl. 1983. The pathogenesis of Group A streptococcal cell wall-induced polyarthritis in the rat: comparative studies in arthritis resistant and susceptible inbred rat strains. Arthritis Rheum. 26:1442-1451.

8. Lehman, T. J. A., J. B. Allen, P. H. Plotz, and R. L. Wilder. 1984. Lactobacillus casei cell wall-induced arthritis in rats: cell wall fragment distribution and persistence in chronic arthritis-susceptible LEW/N and-resistant F344/N rats. Arthritis Rheum. 27:939-942.

9. Allen, J. B., D. Blatter, G. B. Calandra, and R. L. Wilder. 1983. Sex hormonal effects on the severity of streptococcal cell wall-induced polyarthritis in the rat. Arthritis Rheum. 26:560-563.

10. Hunter, N., S. K. Anderle, R. R. Brown, F. G. Dalldorf, R. L. Clark, W. J. Cromartie, and J. H. Schwab. 1980. Cell-mediated immune response during experimental arthritis induced in rats with streptococcal cell walls. Clin. Exp. Immunol. 42:441-449.

11. Vos, J. G., J. G. Kreeftenberg, B. C. Krujit, W. Kruizinga, and P. Steerenberg. 1980. The athymic nude rat II. Immunological characteristics. Clin. Immunol. Immunopathol. 15:229-237.

12. Dische, Z., and L. B. Shettles. 1948. A specific color reaction of methylpentoses and a spectrophotometric micromethod for their determination. J. Biol. Chem. 175:595-603.

13. Mallory, F. B. 1961. Pathologic Technic. W. B. Saunders Company, Philadelphia. 101.

14. Hsu, S. M., and H. J. Ree. 1980. Self-sandwich method. An improved immunoperoxidase technique for the detection of small amounts of antigens. Am. J. Clin. Pathol. 74:32-40.

15. Hsu, S. M., L. Raine, and H. Fanger. 1981. Use of avidin-biotinperoxidase complex $(\mathrm{ABC})$ in immunoperoxidase techniques: a com- 
parison between $\mathrm{ABC}$ and unlabeled antibody (PAP) procedures. J. Histochem. Cytochem. 29:577-580.

16. Stadler, B. M., S. Dougherty, J. J. Farrar, and J. J. Oppenheim. 1981. Relationship of cell cycle to recovery of IL 2 activity from human mononuclear cells, human and mouse T cell lines. J. Immunol. 127: 1936-1940.

17. Krakauer, T., D. Mizel, and J. J. Oppenheim. 1982. Independent and synergistic thymocyte proliferative activities of PMA and IL $1 . J$. Immunol. 129:939-941.

18. Swinscow, T. D. V. 1978. Statistics at Square One. Fourth edition. Dawson and Goodhall Ltd., The Mendip Press, Bath, England. 33-42; 54-56.

19. Allen, J. B., G. B. Calandra, and R. L. Wilder. 1983. Cutaneous inflammatory reactions to Group A streptococcal cell wall fragments in Fisher and Lewis inbred rats. Infect. Immun. 42:796-801.

20. Greenblatt, J., R. J. Boackle, and J. H. Schwab. 1978. Activation of the alternate complement pathway by peptidoglycan from streptococcal cell wall. Infect. Immun. 19:296-303.

21. Lambris, J. D., J. B. Allen, and J. H. Schwab. 1980. In vivo changes in complement induced with peptidoglycan-polysaccharide polymers from streptococcal cell walls. Infect. Immun. 35:377-380.

22. Schwab, J. H., J. B. Allen, S. K. Anderle, F. Daldorf, R. Eisenberg, and W. J. Cromartie. 1982. Relationship of complement to experimental arthritis induced in rats with streptococcal cell walls. Immunology. 46: 83-88.

23. Kohashi, O., C. M. Pearson, Y. Watanabe, S. Kotani, and T. Koga. 1976. Structural requirements for arthritogenicity of peptidoglycans from Staphylococcus aureus and Lactobacillus plantarum and analogous synthetic compounds. J. Immunol. 116:1635-1639.

24. Clark, R. L., M. C. Marr, J. H. Schwab, and W. J. Cromartie. 1983. Microangiographic studies of experimental erosive synovitis in rats. Invest. Radiol. 18:257-263.

25. Fossum, S. 1983. The density and distribution of W3/13, OX19, $\mathrm{W} 3 / 25$ and $\mathrm{OX} 8$ positive cells in nude rat (mu) lymph nodes. Transplant. Proc. 15:1638-1639.

26. Yocum, D. E., J. B. Allen, R. L. Wilder, and S. M. Wahl. 1984. Inhibition of streptococcal cell wall-induced arthritis and hepatic granuloma by cyclosporin A. Fed. Proc. 43:1619. (Abstr.)

27. Haraoui, B., J. B. Allen, E. Helfgott, M. B. Sporn, C. Brickerhoff, and R. L. Wilder. 1984. Dose-dependent suppression by 4-hydroxyphenyl retinamide on streptococcal cell wall-induced arthritis in rats. Arthritis Rheum. 27:S68. (Abstr.).

28. Wood, D. D., E. J. Ihrie, C. A. Dinarello, and P. L. Cohen. 1983. Isolation of an interleukin-1-like factor from human joint effusions. $\mathrm{Ar}$ thritis Rheum. 26:975-983.

29. Decker, J. L. (moderator), D. G. Malone, B. Haraoui, S. M.
Wahl, L. Schrieber, J. L. Klippel, A. D. Steinberg, and R. L. Wilder. 1984. Evolving concepts of pathogenesis and therapy of rheumatoid arthritis. Ann. Intern. Med. 101:810-824.

30. Wahl, S. M., D. G. Malone, and R. L. Wilder. 1985. Spontaneous production of fibroblast activating factor(s) by synovial inflammatory cells. J. Exp. Med. 161:210-222.

31. Klareskog, L., R. Holmdahl, E. Larsson, and H. Wigzell. 1983. Role of T lymphocytes in collagen II induced arthritis in rats. Clin. Exp. Immunol. 51:117-125.

32. Taurog, J. D., G. P. Sandberg, and M. L. Mahowald. 1983. The cellular basis of adjuvant arthritis. 1. Enhancement of cell-mediated passive transfer of concanavalin A by immunosuppressive pretreatment of the recipient. Cell. Immunol. 75:271-282.

33. Taurog, J. D., G. P. Sandberg, and M. L. Mahowald. 1983. The cellular basis of adjuvant arthritis. II. Characterization of the cells mediating passive transfer. Cell. Immunol. 80:198-204.

34. Currey, H. L. F., and M. Ziff. 1968. Suppression of adjuvant disease in the rat by heterologous antilymphocyte globulin. J. Exp. Med. 127:186-203.

35. Pearson, C. M., and F. D. Wood. 1964. Passive transfer of adjuvant arthritis by lymph node or spleen cells. J. Exp. Med. 120:547-560.

36. Waksman, B. H., and C. Wennersten. 1963. Passive transfer of adjuvant arthritis in rats with living lymphoid cells of sensitized donors. Int. Arch. Allergy 23:129-139.

37. Whitehouse, D. J., M. W. Whitehouse, and C. M. Pearson. 1969. Passive transfer of adjuvant-induced arthritis and allergic encephalomyelitis in rats using thoracic duct lymphocytes. Nature (Lond.). 224: 1322.

38. Kayashima, K., T. Koga, and K. Onoue. 1976. Role of T lymphocytes in adjuvant arthritis. I. Evidence for the regulatory function of thymus-derived cells in the induction of the disease. J. Immunol. 117: 1878-1882.

39. Kayashima, K., T. Koga, and K. Onoue. 1978. Role of T lymphocytes in adjuvant arthritis. II. Different subpopulations of T lymphocytes functioning in the development of the disease. J. Immunol. 120:1127-1131.

40. Kohashi, O., C. M. Pearson, N. Tamaoki, A. Tanaka, K. Shimamura, A. Ozawa, S. Kotani, M. Saito, and K. Itioki. 1981. Role of thymus for $N$-acetyl-muramyl-L-alanyl-D-isoglutamine-induced polyarthritis and granuloma formation in euthymic and athymic nude rats or in neonatally thymectomized rats. Infect. Immunol. 31:758-766.

41. Kohashi, O., K. Aihara, A. Ozawa, S. Kotami, and I. Azuma. 1982. New model of a synthetic adjuvant, $N$-acetylmuramyl-D-alanylD-isoglutamine-induced arthritis: clinical and histologic studies in athymic nude and euthymic rats. Lab. Invest. 47:27-31. 